\title{
THE BILL OF RIGHTS AND THE EMERGING DEMOCRACIES
}

\author{
JACEK KURCZEWSKI* AND BARRY SULLIVAN**
}

INTRODUCTION

The modern bill of rights bears little resemblance to the original American renditions, either in their genesis in the Virginia Constitution of 1776 or their promulgation in the first Ten Amendments to the United States Constitution in 1791. There is universal concurrence that the concept of human rights evolved during the subsequent two centuries. There is also universal agreement that America's Founding Fathers erred in omitting the guarantee of such rights from the 1787 Philadelphia Constitution. ${ }^{1}$

This statement directs our attention to the longstanding phenomenon of the globalization of rights. Albert Blaustein observes that, of the two constitutions that soon followed the adoption of the United States Constitution of 1787, one-the Polish Constitution of May 3, 1791-followed the American model and contained no bill of rights, ${ }^{2}$ while the other-the French Constitution of

Copyright (C) 2002 by Jacek Kurczewski and Barry Sullivan

This article is also available at http://www.law.duke.edu/journals/65LCPKurczewski.

* Vice-Dean and Chair of Sociology of Custom and Law, Institute for Applied Social Sciences, University of Warsaw. Deputy Speaker of the Polish Sejm (parliament), 1991-1993.

** Partner, Jenner \& Block, Chicago, Illinois; Fulbright Professor, Faculty of Law and Administration, University of Warsaw, Fall Semester 2001. The authors are grateful to Daniel Shim, who provided invaluable assistance in the preparation of this essay for publication.

1. Albert P. Blaustein, Rights, Human Rights and Constitutional Rights, in THE ORIGINS OF Human Rights: Proceedings at THE SEMINAR Held at NicOlaus Copernicus University 93-110 (Janusz L. Justynicki ed., 1991).

2. This is the common view. It is also true, however, that the Polish Constitution of 1791 included the Charters of Rights and Freedoms as previously given to the nobility:

We recognize all the nobility to be equal among themselves, not only in seeking for offices and for discharge of services to the country that bring honour, fame or profit, but also in the equal enjoyment of the privileges and prerogatives to which the noble estate is entitled, and above all we desire to preserve and do preserve the sacred and intact rights to personal security, to personal liberty, and to property, landed and movable, even as they have been the title of all from time immemorial, affirming most solemnly that we shall permit no change or exception in law against anyone's property and the government instituted by it shall lay no claims to any citizen's property in part or in whole under pretext of jurium regalium or any other pretext whatsoever. Wherefore we do respect, vouchsafe and confirm the personal security of, and all property rights belonging to, anyone, as the true bond of society, as the corner-stone of civil liberty, and we desire that they remain respected, ensured and inviolate for all time to come.

Polish Const. of 1791, art. III (emphasis added). These rights, especially the old neminem captivabimus nisi iure victum principle (the Polish equivalent of Habeas Corpus, established in 1342) had been extended by special laws to the burghers and to Jews. Stanislaw Salmonowicz, Les Droits de l'homme dans la Constitution du 3 Mai 1791 et la tradition des libertés de la noblesse polonaise, in THE ORIGINS OF HUMAN RIGHTS, supra note 1, at 59. The Constitution also reiterated the freedom of practicing all religions, notwithstanding the official status of the Catholic faith, and placed contracts between landlords and peasants under the protection of the government. Professor Salmonowicz also points to the 
September 3, 1791-contained a bill of rights, incorporating the Declaration of the Rights of Man and Citizen of August 26, 1789. ${ }^{3}$ By adopting the Declaration of Rights as part of their constitution, the French followed in the footsteps of Virginia (which had adopted the Virginia Declaration of Rights of July 12, 1776, more than a fortnight before the Virginia Constitution of 1776 was adopted), while the Bill of Rights was added to the United States Constitution as its first ten amendments on December 15, 1791, after the French had incorporated the Declaration of Rights into their constitution.

Although the delegates to the federal convention did not think that the creation of a bill of rights was a necessary part of their work, several of the thirteen original American states already had formulated declarations of rights, and James Madison was able to prepare a draft bill of rights in short order during the First Congress. ${ }^{4}$ Significantly, Madison understood the need for individuals to be protected against the excesses of a local majority, and unsuccessfully

political tactics that caused the reformers to abandon a new text of Basic Rights which had been drafted in the summer of 1790 (based on the oath sworn by Polish kings upon assuming the throne since the fifteenth century), and put forward the political Constitution that almost was accepted in a coup in May 1791, despite opposition both from conservative elements and from the neighboring powers that would soon partition Poland. Id. at 59. First, however, constitutional principles as drafted in 1789 included reference to "freedom, property and equality of citizens," later changed by Sejm to "property," while in 1790 "those [provisions] leading to ... personal freedom to the right of neminem capitvabimus for all inhabitants, to vote freely were unanimously accepted in five articles." FRANCIXZEK XAWERY DMOCHOWSKI, O USTANOWIENIU I UPADKU KONSTYTUCYI POLSKIEJ 3GO MAJA 1791 [ON THE ESTABLISHMENT AND FALL OF THE POLISH CONSTITUTION OF MAY 3D 1791] 129 (J.Maj, 1793).

3. Id. at 59. In the United States, the argument against having a bill of rights attached to the federal constitution involved philosophical questions about the need for a bill of rights in a republican government, but also turned on the respective roles of state and national governments in a federal system, on the limited powers of the national government, and on the checks and balances inherent in the design and structure of the federal government. In FEDERALIST 84, Hamilton made the point succinctly: "The truth is, after all the declamation we have heard, that the constitution is itself in every rational sense, and to every useful purpose, A BILL OF RIGHTS." THE FEDERALIST NO. 84, at 581 (Alexander Hamilton) (J. Cooke ed., 1961).

4. The Virginia Declaration of Rights of 1776, the Pennsylvania Declaration of Rights of 1776, and the Massachusetts Declaration of Rights of 1780 were particularly influential. See generally, THE FOUNDERS' CONSTITUTION (Philip B. Kurland and Ralph Lerner eds., 1987); see also generally Gordon S. WoOd, THE CREATION OF THE AMERICAN REPUBLIC, 1776-1787, 271-72 (1969). Jack Rakove has provided a detailed account of American political thinking about rights in the late eighteenth century. JACK N. RAKOVE, ORIGINAL MEANINGS: POLITICS AND IDEALS IN THE MAKING OF THE CONSTITUTION 288-338 (1996). Thus, Professor Rakove has written:

Americans entered the Revolutionary crisis confident that they knew what their rights were; after independence, they modified these ideas only modestly. What did evolve, far more dramatically and creatively, were their ideas of where the dangers to rights lay and how rights were to be protected. At the outset Americans believed that arbitrary acts of the Crown and its colonial officials, including judges of the higher courts, posed the greatest threat, and they accordingly treated the rights of representation and trial by jury as their chief securities against arbitrary rule. It took a decade of experience under the state constitutions to expose the triple danger that so alarmed Madison in 1787: first, that the abuse of legislative power was more ominous than arbitrary acts of the executive; second, that the true problem of rights was less to protect the ruled from their rulers than to defend minorities and individuals against factious popular majorities acting through government; and third, that agencies of central government were less dangerous than state and local despotisms. This recognition marked a significant departure in Anglo-American thinking about rights, and it helps to explain why Federalist qualms about the utility of bills of rights involved more than political oversight. Id. at 289-90. 
sought to include the following provision in the bill of rights: "No state shall violate the equal rights of conscience, or the freedom of the press, or the trial by jury in criminal cases." Many years would pass before the substance of this provision would become part of American jurisprudence as a result of the adoption of the Civil War Amendments and twentieth century judicial decisions. ${ }^{6}$ However, many other aspects of the federal constitution, as initially adopted, reflect both the framers' distrust of unfettered democracy and their preference for constitutionalism. Walter Murphy, in an important essay on the relationship of constitutionalism and democracy, has noted that "[c]onstitutionalists tend to be more pessimistic about human nature, fearing that people are sufficiently clever to oppress without hurting themselves."

By the end of the eighteenth century, model bills of rights were being circulated throughout the globe; that phenomenon continues today, when the rights contained in these eighteenth century statements of rights have been codified, amplified, and multiplied, both in domestic constitutions and in regional and international declarations and covenants. Today, the influence of the American Bill of Rights can be traced through its remote offspring, including the Helsinki Agreement, ${ }^{8}$ the German Basic Law, ${ }^{9}$ the post-war French constitutions, ${ }^{10}$ and the European Convention on Human Rights. ${ }^{11}$ These documents, perhaps even more than the American Bill of Rights itself, have influenced recent developments in the emerging democracies of eastern and central Europe, which were under the communist regime from 1918, in the case of eastern Europe, or 1945, in the case of central Europe, until the regime began to break down in $1989 .{ }^{12}$

5. Id. at 335 .

6. See Pauline Maier, American Scripture: Making the Declaration of INDEPENDENCE 207 (1997) ("[T]he North fought not only to save the Union, but to save a form of government, as Lincoln told Congress on July 4, 1861, 'whose leading object is to elevate the condition of men; to lift artificial weights from all shoulders-to clear the paths of laudable pursuits for all-to afford all an unfettered start and a fair chance in the race of life."').

7. Walter F. Murphy, Constitutions, Constitutionalism, and Democracy, in ConstiTUTIONALISM \& DEMOCRACY: TRANSITIONS IN THE CONTEMPORARY WORLD 3, 5 (Douglas Greenberg et al. eds., 1993).

8. Final Act of Conference of Security and Co-operation in Europe, Aug. 1 1975, § 1(a)VII, available at www.house.gov/cse/finalact.htm.

9. F.R.G. CONST. (Basic Law for the Federated Republic of Germany), arts. I-XVII.

10. See FR. CONST. of 1946, Preamble, available at www.justice.gouv.fr/anglais/textfond/ction46.htm; FR. CONST. of 1958, Preamble and art. I, available at http://www.assemblee-nationale.fr/english/8ab.asp.

11. Convention for the Protection of Human Rights and Fundamental Freedoms, as amended by Protocol no. 11, opened for signature Nov. 4, 1950, arts. III-XIV, Europ. T.S. No. 5; Convention for the Protection of Human Rights and Fundamental Freedoms, as amended by Protocol no. 12, opened for signature Nov. 4, 2000, Europ. T.S. No. 177.

12. In Poland, these influences also included an indigenous tradition with respect to individual rights. See JACEK KURCZEWSKI, The Resurrection OF Rights In POLAND (1993). In addition, the Solidarnosc movement was influenced by the official documents of the Second Vatican Council and subsequent developments in Catholic social teaching. T. GARTON ASH, THE POLISH REVOLUTION: SOlidARITY 66 (rev. ed. 1999) [hereinafter ASH, THE POLISH REVOLUTION]; see also T. GARTON ASH, History OF THE PRESENT: ESSAYS, SKETCHES AND DisPATCHES FROM EUROPE IN THE 1990S (1999). 
In the twentieth century, the idea of basic rights became so widely accepted, at least in theory or rhetoric, and was subject to so many different usages, that it is difficult to locate a clear and consistent understanding of the concept. After all, even communist regimes claimed to respect human rights-a claim which eventually undermined and hastened the disintegration of those regimes, as the claim was taken seriously by the people. Nonetheless, as Wiktor Osiatynski, a noted expert on American and Eastern European constitutionalism, has observed, the central problem in giving effect to human rights in the political transformation and constitution-building process in East Central Europe was not the definition of rights, but the creation of effective mechanisms for their protection and enforcement: "The progression from the socialist concept of rights to post-communist constitutionalism lies primarily in the realm of protection." 13

It is unnecessary to belabor the superficial character of the recognition of basic rights in Stalin's Soviet constitution of $1936^{14}$ and the many communist-style constitutions that followed. In essence, Soviet "law" was dominated by an extreme, "positivist" ideology of rights. After initial periods of revolutionary and post-revolutionary turbulence, basic rights were returned to an already terrorized society under the scrutiny of Stalin's obedient follower, A.N. Vyshinskyi. No idealist or "bourgeois" formula of inalienable rights was acknowledged: Rights were bestowed at the will of the Soviet state and Stalin's constitution, and were subject to revocation or suspension at the will of the state. $^{15}$ The Party, as the revolutionary vanguard elite, situated itself above the

13. Wiktor Osiatynski, Rights in New Constitutions of East Central Europe, 26 COLUM. HUM. RTS. L. REV. 111, 111 (1994). Interestingly, Judge Wisdom made the same point during the period of the American civil rights movement of the 1960s. Notwithstanding the doctrinal innovations which followed in the wake of the Supreme Court's decision in Brown v. Board of Education, 347 U.S. 483 (1954), Judge Wisdom wrote that "In civil rights cases the problem of enforcement is far more difficult than the problem of legislative or judicial definition." John M. Wisdom, The Frictionmaking, Exacerbating Role of Federal Courts, 21 Sw. L.J. 411, 424 (1967); see also generally OWEN M. FISS, THE CIVIL RIGHTS INJUNCTION (1978). Commenting on the situation in Northern Ireland in 1994, Conor Gearty pointed to the inherent limitations of a system that relies on judicial enforcement:

It is the job of judges to uphold the status quo. They are schooled in law and order. To expect them to subvert authority is like asking the headmaster to disrupt a teacher's class. The real critics of the judiciary are those liberals who see the judges as the route to a magically just and fair society, as capable, if only they flexed their creative muscles, of transforming the relationship between the individual and the state... Human rights are "human" and they are ours to fight for-they are not for others to guarantee on our behalf.

Conor Gearty, The Cost of Human Rights: English Judges and the Northern Irish Troubles, in 47:2 Current Legal Problems 19, 40 (M. Freeman \& R. Halson eds., 1994).

14. KONST. USSR (1936).

15. As Ewa Letowska has written, "the basic law was relegated to a mere declaration of the political authority's good intentions; its normative content was meager, and effective enforcement mechanisms of constitutional provisions largely absent." Ewa Letowska, Courts and Tribunals in Poland, in CONSTITUTIONAL ESSAYS 191, 191-92 (Miroslaw Wyrzykowski ed., 1999). If there is a necessary connection between the concept of "rights" and the rule of law, it is difficult to square this reality with Michael Ignatieff's view that "[t]here were two human rights cultures after 1945," and that the "Communist rights tradition - which put primacy on economic and social rights-kept the capitalist rights tradition emphasizing political and civil rights from overreaching itself." Michael M. Ignatieff, Human Rights as Politics, in Human Rights AS POlitics AND IDOLATRY 19 (A. Guttman ed., 2001). This use of the term "human rights culture" grants too much legitimacy to the practice it describes. As Pro- 
state, and reserved to itself the arbitrary power to decide which of the rights declared in the constitution were to be guaranteed, to whom they would be guaranteed, against whom they would have effect, and how they would be implemented. ${ }^{16}$ Given this legacy, it is not surprising that the authors of a study of post-communist transitions in several countries of Eastern Europe should have found that "[a]ll constitutions under study reveal a strong commitment of their drafters to the legally binding force of the constitution, i.e., to the essential idea of constitutionalism." ${ }^{17}$

The demand for constitutional security is understandable in these societies, which suffered so long from the arbitrariness with which "law," including constitutional law, was implemented. Needless to say, prevailing ideas of constitutionalism in the region now place a strong emphasis on human rights and their enforcement. Indeed, this emphasis on rights was especially evident at the beginning of the period of transformation, at least in those countries where there was endemic implosion, influenced as well by Soviet perestroika and the Polish Round Table talks. In Hungary, for example,

During preparatory work on the [1989] amendments to the Constitution, the opposition Round Table proposed that changes to the structure of the Constitution should reflect the belief that human rights are henceforth to be regarded as basic values. According to this conception, such rights are not privileges granted by the state in the exercise of its discretion but-on the contrary-they are the very limits of state power. According to the Opposition Round Table, it was still acceptable that rights which were "secured" by the state should be put in a chapter after a chapter dealing with the

fessor Osiatynski has observed, "socialist constitutionalism" treated individual rights as "benefits" granted by the state in return for the fulfillment by citizens of the duties they owed to the state; emphasized social and economic benefits over political and civil rights; and were subject to limitation when they were seen to conflict with the "public good" or "principles of social cooperation." Osiatynski, supra note 12 , at 112 .

16. An interesting comparison may be made with the Japanese Constitution of 1946. As Kyoko Inoue has noted:

Through the consistent use of the modal "shall," the U.S. Constitution conveys the people's commitment to a representative government and their command to their government not to abridge their rights and liberties. The Meiji [pre-war] Constitution had an entirely different illocutionary force, reflecting the Japanese government's assertion, in the name of the Emperor, of both its authority and its responsibility to govern the nation for the welfare or benefit of the people.

Kyoko Inoue, MacArthur's Japanese Constitution: A Linguistic And Cultural Study OF ITS MAKING 102 (1991) (emphasis added). As Professor Inoue has further noted, the text of the Japanese Constitution of 1946 is contained in parallel English and Japanese versions, which are not translations and actually "convey different illocutionary forces." Id. The language of the English text, written by Americans, is similar in tone to that of the United States Constitution. In the Japanese text, by contrast, "the people do not command the government not to infringe their rights and liberties." Id. at 103. Instead, as Professor Inoue has noted:

[The Japanese text] affirms the responsibility of the Japanese government to establish a democratic government, and the people and the government together affirm the necessity of protecting individual rights and liberties. Thus, this text continues in a significant way the political tradition of Meiji Japan, in which the government took the authority and responsibility to govern the nation well. But it adds an important new element: the participation of the people in the political process.

Id. at 103 .

17. Jon Elster et Al., InStitutional Design in Post-COMMUNist Societies: RebUilding THE SHIP AT SEA 107 (1998). 
organs of the state. However, basic rights, which limited state power, should precede those parts of the constitution dealing with state organs. ${ }^{18}$

Other participants in the Hungarian negotiations, including the communists, objected to this change on the ground that it was too great, and would transcend a simple amendment of the Stalinist constitution of 1949, which was the stated purpose of the negotiations. A compromise was eventually reached, however, when the participants agreed that Chapter One of the Constitution would be amended to include the singularly important statement that "the Hungarian Republic recognizes the inviolable and inalienable rights of man, and that their respectful observance and protection is the first and foremost duty of the state." $" 19$

Following the adoption of these 1989 amendments to the Stalinist constitution of 1949, which prepared the way for de-communization in Hungary, an additional series of amendments, as agreed between the ruling and opposition parties, was made in the spring of 1990. In the latter set of amendments, the parties agreed to omit "restrictions reminiscent of those found in certain international human rights agreements ... from the modified Constitution; in their place it was decided to insert a formulation found in the German Basic Law prohibiting the restriction by law of the essential content of the human rights." ${ }^{20}$ These amendments also left the task of interpretation to the Constitutional Court.

Czechoslovakia and Russia each incorporated a bill of rights into their constitutions before the fall of communism. Before Czechoslovakia separated into two nations, it attempted, unsuccessfully, to agree on a new federal constitution. In 1991, however, in what has been called its "most notable achievement," Czechoslovakia did manage to promulgate a federal bill of rights. ${ }^{21}$ The Charter of Fundamental Rights and Freedoms was drafted with the assistance of Western European and American experts. It was made directly applicable in the courts and provided individuals with a system of judicial remedies; it was protected by the Constitutional Court; and its provisions were to take precedence over other constitutional, statutory, and regulatory provisions. ${ }^{22}$ In different ways, following the division of Czechoslovakia, various provisions of the charter later became part of the fundamental law of both the Czech Republic and the Republic of Slovakia. ${ }^{23}$ In a similar vein, Russia first incorporated its Declara-

18. Gabor Halmai, The Protection of Human Rights in Poland and Hungary, in HUMAN RIGHTS IN EASTERN EUROPE 161 (Istvan Pogany ed., 1995).

19. A Magyar Koztarsasag Alkotmanya [CONSTitution] art. 8, sec. 1 [hereinafter Hung. CONST.].

20. Halmai, supra note 18 , at 162 .

21. ELSTER ET AL., supra note 17, at 73.

22. Osiatynski, supra note 13 , at 117.

23. Id. Osiatynski has written: "The Czech Constitution of December 16, 1992, did not incorporate the charter into its text [but] ... stated that 'The Charter of Fundamental Rights and Freedoms is part of the constitutional order of the Czech Republic' and reconfirmed that 'fundamental rights and freedoms shall enjoy the protection of the judicial power."' Id. at 117-18 (footnotes omitted). The Slovak Constitution of September 1, 1992, incorporated the charter into its text but with some modifications, such as the lessening of protection for minority rights and the enhancement of protections for economic, cultural, and social rights. Id. at 118 . 
tion of Rights into the Brezhnev-era Constitution of the Russian Federal Soviet Socialist Republic in 1992, and then into the current Constitution of the Russian Federation, which was adopted by referendum on December 12, 1993. ${ }^{24}$

These declarations of rights, as well as others, had their origins in the will of reformers and dissidents, who aimed at ending the duplicity into which the socalled "socialist" world had fallen, as its secret and uniformed police attempted to quell the aspirations of those who sought to ensure the enjoyment of human rights in their societies. In Poland, the dissident movement, which was made possible and encouraged by the Helsinki agreement, sparked the creation of "Solidarnosc," which, in 1980, became the first independent trade union recognized by communist authorities. The First Congress of Solidarnosc, which met in Gdansk-Oliwa in the fall of 1981, specifically addressed the subject of human rights and law reform. The First Congress of Solidarnosc, included the following, as Thesis 23 , in its final resolution:

[The] legal system must guarantee basic civic freedoms, [and] respect principles of equality of all citizens and all institutions of public life before the law.

This requires:

1. Implementing principles and decisions of international conventions, especially international covenants of rights, ratified by Poland. We see the safeguarding of it in ratifying by [the] Polish People's Republic the Optional Protocol of the International Covenant of Civic and Political Rights, that foresees international control of implementation of the Covenant.

2. Clear formulation in the Constitution of the principle of equality of citizens, also independent of their beliefs, political views, and organizational affiliation.

3. Subordination of all elements of public life, including the political and social organizations, to law. It is therefore necessary to change the constitutional regulations referring to the legal status of these organizations and unequivocal clarification of their legal relationship with Sejm [Polish House of Deputies] and other agencies of administration.

4. Setting up of the independent Constitutional Tribunal (or the equivalent Chamber of the Supreme Court), the task of which shall be judging the constitutionality of legal statutes and the legality of legal decisions of lower rank. The concordance of national law with the ratified conventions and International Covenants of Rights should also be reviewed.

5. Amendment of law on assemblies, associations and passports (law on passports should include the right to choose freely residence abroad and the right to return to Poland). Decisions restricting civic freedoms should be subject to judicial control.

6. Introducing the full transparency of public life, one of the conditions of which is the access of citizens to documents of administration. Restrictions on transparency of public life and access to documents should be clearly set forth by the statute. ${ }^{25}$

24. Stephen C. Thaman, Trial by Jury and the Constitutional Rights of the Accused in Russia, 4:1 E. EUR. CONST. REV. at 77, 78 (1995). Thaman points out that these constitutional developments were linked to, and assisted in, Mikhail Gorbachev's criminal justice system reform efforts of 1988-89. Id. at 77-78.

25. SOlidARNOSC, I KRAJOWY ZJAZD DELEGATOW NSZZ, UCHWALA PROGRAMOWA Z Aneksem [Program Declaration With APPEndiX], Gdansk, 1981; see also Ash, The Polish REVOLUTION, supra note 8, at 216-43 (account of the First Congress). 
Thesis 23, which contains Solidarnosc's clear demand for constitutional change, was understood by communist politicians as a threat and intrusion into the core of their political domain-from which the reluctantly legalized trade union was intended to keep its distance. Though cryptic, the language of Thesis 23 expresses Solidarnosc's objective of curtailing the unconstitutional power of both the communist party and its satellite "political and social organizations," as well as that of the ministry of interior and the "administrative agencies" of the secret police. In addition, Solidarnosc made a direct demand for representative government in Thesis 22, a motion that was fatal for Solidarnosc in the short term, but which has since proved to be the most prophetic and consequential of the trade union's efforts. ${ }^{26}$ In Thesis 24, Solidarnosc demanded that "courts must be independent, and prosecution subject to social control," and in Thesis 25 provided that no one "should be persecuted for beliefs or forced to act against conscience." ${ }^{27}$

The demands made by Solidarnosc were remarkable for their time and place; that Solidarnosc could exist at all was also remarkable, and was made possible only because of indigenous conditions and the tide of rising expectations that was released by the Helsinki Agreement. ${ }^{28}$ In any event, in the latter part of the twentieth century, human rights ceased to be the pursuit of idealistic goals by a handful of volunteers, but took on normative strength, becoming a body of law with its own market, its own professional specialization, and its own institutions. One may even cynically observe that it also became a new business for lawyers and a new rhetorical device for politicians. Whatever suspicions we might justifiably entertain, however, human rights law must be taken as a serious step into a new way of thinking about individual and collective relations. Thus, it is appropriate to point to some features of human rights law that seem to be singularly important.

First, the law of human rights is transnational; in fact, human rights law has developed so as to place restraints on the actions of individual states, with respect both to their own citizens and to others. However skeptical one may be as to the effectiveness of this control, one need only recall the reluctance of communist countries to accept the human rights law provisions of the Helsinki Agreement - a reluctance that proved wholly justified in retrospect (at least from the viewpoint of their ruling elites), as the linkage between international monitoring processes and gradual de-communization became clear. Human

26. In Thesis 22 , Solidarnosc demanded that genuine representation should exist at the highest national level: "We shall strive for recovery of the supreme power of the country by the Sejm, as well as to that the changed electoral law will reestablish its widely acknowledged representative character by allowing all political parties, social organizations and groups of citizens the nomination of candidates" in elections. SOLIDARNOSC, supra note 25 , at 27 . This demand was construed by the Communist party as a declaration of civil war and was used by General Jaruzelski to justify the imposition of martial law on December 13, 1981. NORMAN DAVIES, HeART OF Europe: A SHORT History OF POLAND 16-25 (1986).

27. SOLIDARNOSC, supra note 25 , at 24, 25.

28. See, e.g., Michael Ignatieff, supra note 15, at 19. 
rights law thus became a mechanism for easing the development of a legal order capable of keeping pace with the globalization of our relations.

Second, the nature of human rights law is such that it imposes affirmative duties on the state and other political organizations. Instead of the old regime of self-imposed limitations on the authority of the state, as in the Rechtsstaat, ${ }^{29}$ the state is now considered under the rights regime to be one of the many organizations that are placed on a par with the society of individuals who are entitled to its services. No longer does the state dwell entirely in the splendid isolation of absolute sovereignty. ${ }^{30}$

Third, an important aspect of human rights law is its aspirational character. Human rights law mandates that each state implement minimum standards, but the notion of a minimum dialectically entails as well the notion of something more demanding than the minimum - that is, the possible expansion of rights to which people are entitled. Classical notions of morality of duties and morality of aspirations, as developed by Lon L. Fuller in relation to the law in general, seem directly relevant to human rights law. ${ }^{31}$ There is growing support for the idea that an international-or hopefully, supranational-force should be used

29. "Rechtsstaat" is a concept which developed in Germany in the Nineteenth Century, stressing sovereign self-limitation and the obligation of the state to act through law. Professor Michael Rosenfeld has explained:

Rechtsstaat is often treated as the German equivalent to the concept of the rule of law in the Anglo-American tradition. Both concepts share some important elements in common. Chief among these is ... the state's duty to wield its power through laws in accordance with fundamental principles of legality .... Beyond that, however, the two concepts differ significantly, particularly in terms of their understanding of the relationship between the state and the law. Whereas the American conception of the rule of law is rooted in a somewhat antagonistic relationship between the state and the rule of law ... its German counterpart is squarely predicated on a veritable symbiosis between the law and the state. In the broadest terms, in the Rechtsstaat, law becomes inextricably tied to the state as the only legitimate channel through which the state can wield its power. Accordingly, "state rule through law" would be a better approximation in English for 'Rechtsstaat' than "rule of law."

Michael Rosenfeld, The Rule of Law and the Legitimacy of Constitutional Democracy, 74 S. CAL. L. REV. 1307, 1318-19 (2001); see also FRANZ L. NEUMANN, THE RulE OF LAW 45 (1986). See also Jacek Kurczewski, The Rule of Law in Poland, in THE RUle of LAW IN CENTRAL Europe: THE RECONSTRUCTION OF LEgALITY, CONSTITUTIONALISM AND CIVIL SOCIETY IN THE POSTCOMMUNIST COUNTRIES 181, 183 (Jiri Priban and James Young eds., 1999).

30. As Thomas Franck has noted, the limitations on sovereignty exacted by international human rights law have not gone unchallenged. Thomas M. Franck, Are Human Rights Universal?, 80:1 FOREIGN AFFAIRS January/February 2001, at 191-92. Just as the Taliban insisted that its treatment of women should not be judged by outsiders, the United States rebuffs criticism of capital punishment in the United States by asserting that it is "their way and no one else's business." Id. at 192. Michael Ignatieff also has noted that most Americans believe that state statutes authorizing imposition of the death penalty are an "expression of the democratically expressed will of the people," and that "international human rights objections are ... both irrelevant and intrusive." Michael Ignatieff, supra note 15, at 14 .

31. LON L. Fuller, ThE Morality OF LAW 5 (rev. ed. 1969). Fuller believes the "morality of aspiration" to be best exemplified in Greek philosophy. He writes that "[i]t is the morality of the Good Life, of excellence, of the highest realization of human powers." Id. When a person fails to achieve that excellence and is found wanting, she is "condemned for failure, not for being recreant to duty; for shortcoming, not for wrongdoing." Id. On the other hand, "[w] here the morality of aspiration starts at the top of human achievement, the morality of duty starts at the bottom ... [laying] down the basic rules without which an ordered society is impossible, or without which an ordered society directed towards specific goals must fail of its mark." Id. at 5-6. 
to bring an abusing state back in line with minimum expectations. At the same time, there is no global consensus about the degree and quality of rights that should be extended by any state beyond the minimum. In this way (as we observe when we consider the extension of civil and political rights into social and economic rights), human rights law becomes a new, developmental type of law. As a matter of fact, such devices as human rights world maps created by organizations like Amnesty International can be seen both as politically efficient instruments for encouraging politicians to foster this development and as measuring rods for ascertaining their degree of definition and development.

Fourth, and philosophically most intriguing, the development of human rights law has affirmed the possibility of a dialectical reformulation of the normative order. Although some developments in human rights law were the result of unilateral actions taken by a superior power, such as the Nuremburg and Tokyo trials, most of human rights law history was made through boring hours of debate in which participants formally agreed to subscribe to some common standards, even if the participants may have contemplated deviating from these standards in some respects in the future. ${ }^{32}$ This process of collective discovery and creation of standards to be applied by common agreement seems to be both the essence of the new body of law and the defining characteristic which most clearly distinguishes it from the traditional authoritarian positivism of Behemoth-like state legal systems. In the 1960s and 1970s, of course, the struggle for human rights in Central and Eastern Europe was not a matter of high priority to the American Left because of preoccupation with domestic political controversies, such as the Civil Rights Movement and the war in Vietnam, and because of intellectual reservations about the notion of rights. The spirit of the times was perhaps exemplified by Senator Eugene McCarthy, who, during his presidential campaign in 1968, described the Soviet invasion of Czechoslovakia, and the end of the "Prague Spring," as a matter of little consequence..$^{33}$ The fall of Communism, as an historical event, strengthened overall confidence in the discourse of human rights law, and, among other things, in the reconstruction of criminal law as a necessary and legitimate part of social life, respectful both of its proper purposes and of the constraints necessarily imposed by a proper understanding of human rights.

32. See, e.g., Mary Ann Glendon, A World Made New: Eleanor Roosevelt And the UNIVERSAL DECLARATION OF HUMAN RIGHTS 143 (2001) (discussing the drafting of the Universal Declaration of Human Rights). Professor Glendon has written:

When the third committee turned from its general discussion to the specific provisions of the Declaration, Mrs. Roosevelt was dismayed to find that the members of that large group seemed determined to debate "every single word of that draft declaration over and over again." There was hardly any issue that the human rights commissioners had not thoroughly considered, yet the third committee, she complained, was treating each article "exactly as Id. though it was all an entirely new idea and nobody had ever looked at it before."

33. Commenting on the Soviet invasion of Czechoslovakia, Senator McCarthy stated, "I do not see this as a major world crisis.” CHARLES KAISER, 1968 IN AMERICA 235 (1988). 
Fifth, and by virtue of the features we have previously identified, human rights law has achieved a paramount importance in the contemporary legal order. It now serves as a reference point to judge the validity of national legislation and judicial practice. Its real test in the future, however, may well concern its ability to control the supranational economic organizational links that may, with time, become more of a threat to the rights of individuals than the actions of nation states. Nonetheless, human rights law has already changed the meaning we give to the Rule of Law. If we speak of the Rechtsstaat, we fall victim to using an antiquated notion perpetuated in the usage of the European Union; the Rechtsstaat of today is in fact bound by the requirements of international human rights law, which serve as a pattern against which the particular laws and practices of nations are judged. If so understood, the Rules of Law and Justice are co-extensive.

Scholars have commented on the apparent similarity of the rights protected by the individual constitutions of the emerging democracies, observing that the human rights protected by these constitutions are not typically limited to traditional "negative rights," such as freedom from interference with life, liberty, and property, but also include positive social, mostly non-justiciable rights such as the rights to health care, subsistence, and education. ${ }^{34}$ Moreover, the "negative rights" or "freedoms" are "trans-liberal" in that they tend to include the right to basic institutional preconditions that are required for their implementation. ${ }^{35}$ Three distinguished Western European scholars have stated:

Generally speaking, the study of the post-communist constitutions gives rise to the observation that the boundaries between traditional negative rights and their "trans-liberal" expansion, institutional guarantees, and positive rights are in flux. The order of this spectrum mirrors a decreasing degree of judicial enforceability and of an increasing necessity for political and administrative discharge of the respective state obligations. Moreover, a great number of institutional guarantees and positive rights causes the institutional after-effect of a shift of state authority from the courts to the other branches of government, primarily to the executive branch. ${ }^{36}$

\section{Amy Gutman has written:}

Human rights protect the core of negative freedom, freedom from abuse, oppression, and cruelty. This is a starting point for some complex thinking about what the purpose and content of the evolving international human rights regime should be. But even the starting point is more complex - and contestable - than first appearances might suggest. Protecting human agencies, and protecting human agents against abuse and oppression, cannot be identified simply (or solely) with negative liberty, freedom from interference. Nor is the core of human rights constituted only by negative freedoms. The right to subsistence is as necessary for human agency as a right against torture.

Amy Gutman, Introduction in Michael IgNATIEFF, Human Rights As POLITICS AND IDOLATRY ix (Amy Gutman ed., 2001); see also Isaiah Berlin, Two Concepts of Liberty, in THE PROPER STUDY OF MANKIND 191, 194, 203 (Henry Hardy \& Roger Hausheer eds., 1998) ("I am normally said to be free to the degree to which no man or body of men interferes with my activity. Political liberty in this sense is simply the area in which a man can act unobstructed by others .... The positive sense of the word 'liberty' derives from the wish on the part of the individual to be his own master. I wish my life and decisions to depend on myself, not on external forces of whatever kind.")

35. ELSTER ET AL., supra note 17, at 82.

36. ELSTER ET AL., supra note 17 , at 87. 


\section{II}

\section{INSTITUTIONAL REMEDIES}

As is commonly observed in the literature, the founders of the new constitutional order in the emancipated states of Central and Eastern Europe, such as Hungary, Poland, and Czechoslovakia, agreed that the fundamental task of constitutional change involved not so much the simple identification or listing of rights, but, more importantly, the development of institutions that would adequately safeguard and implement constitutional freedoms and rights. This essay will not attempt an exhaustive review of all of the efforts made in the post-communist period to fulfill this expectation. Pointing to some elements in the process of institutionalizing the protection of rights will suffice to illustrate the problems faced by these developing democracies and the accomplishments they realized. In some cases, newly created positions, such as the office of the ombudsman in Poland, as well as constitutional courts there and in various other countries, have often exceeded original expectations for the safeguarding of constitutional protection, while such factors as the persistence of the Russian-model procuracy, even in countries where it existed by virtue of colonial importation, have contributed to institutional inertia and have made the process of change more arduous and complicated.

\section{A. The Polish Ombudsman}

Among the ombudsman offices that now exist around the world, some are weak and some strong; the Polish version certainly is among the strongest of these offices. The explanations for the strength of the Polish version are both structural and historical. The ombudsman is appointed by Parliament and is accountable to it. ${ }^{37}$ The ombudsman serves a four-year term (not coterminous with the parliamentary term), can be removed only for causes enumerated in the Ombudsman Act, and may be reappointed only once. ${ }^{38}$ The ombudsman's competence extends to all cases where civil rights or civil liberties have been infringed by state administrative officials; the ombudsman may file judicial pro-

37. Ewa Letowska, The Ombudsman and Basic Rights, 4:1 E. EUR. CONST. REV., Winter 1995, at 63. The office of ombudsman was first created in Sweden by the Swedish Constitution of 1809. WALTER GELlHORN, OMBUDSMEN AND OTHERS 194 (1966). Under the Swedish model, the ombudsman's primary responsibility is to act as a watchman who supervises the observance of laws and statutes by public officials. Id. at 205. Although much of the job of the ombudsman is to hear and respond to complaints by citizens with grievances, the ombudsman also has the ability to proceed on his own motion when problems come to his attention. Id. at 208. The ombudsman does not have the power to give orders, but does have the power to prosecute an official for careless breaches of duty, as well as the power to give "reminders" to erring officials. Id. at 203-04. Since its appearance in Sweden, the office of the ombudsman has been adopted, in various forms and permutations, in many other countries. Although the position is not common in the United States, it has been adopted for the Internal Revenue Service. See I.R.C. § 7803(c) (West 2002); National Taxpayer Advocate's 2001 Annual Report to Congress, available at http://www.irs.gov/pub/irs-utl/2001_tas.pdf.

38. Id. 
ceedings to enforce rights and also may seek disciplinary proceedings against government officials without regard to their rank. ${ }^{39}$

The office of ombudsman was introduced into the scheme of government in Poland in 1988, during the final decay of communist rule-after the reestablishment of both the Highest Administrative Court (1980) and the Tribunal of State (1982), and after the establishment of the Constitutional Tribunal (1985). ${ }^{40}$

The first Polish ombudsman, Professor Ewa Letowska, has written that

Creation of the [ombudsman's] office was, in effect, one more concession by the collapsing regime. By establishing these institutions, the communists clearly aimed to improve their credibility and image at home and abroad ....

Communist officials, largely ignorant of the nature of this institution [modeled after the Swedish original version], agreed to establish [the office of the] ombudsman without realizing the potential consequences. The communists probably assumed that the ombudsman would submit to their wishes. To this end, the government chose a female scholar with no political affiliation and no political experience. Yet, as in several earlier cases-namely, the creation of the Highest Administrative Court and the Constitutional Tribunal-the ombudsman proved to be a surprise that the regime could hardly welcome. ...

In short, the ombudsman was established in Poland as a result of the relative weak and short-sighted communist regime. Later, the institution was able to endure and even consolidate because the new regime was similarly weak and unable to appreciate the impact of the office on state authority. By the time this was discovered by the government, the office was already well-established and widely-supported, thus dooming any attempt even to diminish its status and authority. ${ }^{41}$

On another occasion, Professor Letowska remarked that she would never have accepted the job if she had known that her term of office would coincide with the changing of the regime, as the normal functioning of such an office is possible only where there is political stability and professional administration. ${ }^{42}$ For some, of course, the very fact that this innovation was made by the communist regime was sufficient justification to work for its abolition, without regard to its merits. By the fall of 1990, a group of Solidarnosc members of parliament were drafting a law aimed at restricting the ombudsman's scope of action. Although this initiative came from a minority group, and the majority took the opposite approach when parliament actually broadened the ombudsman's scope of action the following year, the attacks continued both throughout Professor Letowska's term and during the term of her successor, from 1992 to 1996,

39. $I d$.

40. See, e.g., Mark F. Brzezinski \& Leszek Garlicki, Judicial Review in Post-Communist Poland: The Emergence of a Rechstaat?, 31 STAN. J. INT'L L. 13, 20, 26 (1995); Mark F. Brzezinski, The Emergence of Judicial Review in Eastern Europe: The Case of Poland, 41 AM. J. CoMP. L. 153, 171, 173 (1993); Leszek Garlicki, Constitutional Development in Poland, 32 ST. LOUIS L.J. 713, 718-24 (1988).

41. Letowska, supra note 37, at 63.

42. Jolanta Arcimowicz, Funkcjonowanie urzedu Rzecznika Praw Obywatelskich w Polsce [Functioning of the Ombudsman's Office in Poland] 52 (2000) (unpublished Ph.D dissertation, Institute of Applied Social Sciences, Warsaw University) (on file with Warsaw University). 
when Professor Tadeusz Zielinski held the office. ${ }^{43}$ These attacks were linked with the fact that the first two Polish ombudsmen were both involved in a heated controversy over the sudden reappearance of organized religion-that is, of the Roman Catholic Church-in the public sphere. ${ }^{4}$ The old regime had relegated religion to the privacy of homes and churches, leaving no public role for religion at all. With the re-emergence of religion in the public sphere, strong differences of opinion appeared with respect to issues such as the teaching of religion in state schools and the display of religious symbols, including crucifixes, in public places and government offices. The first two ombudsmen were also involved in defending the rights of non-believers, which led to sharp criticism from political groups representing the Catholic Right and some members of the church hierarchy. ${ }^{45}$ These divisive issues soon led to the fragmentation of the formerly united anti-communist opposition.

Much that Professor Letowska concluded in 1995 has now proved true. Certainly, she was correct in observing that the ombudsman's position, once established, proved an important check on the government and administration. In retrospect, however, one may wish to add to her judgment on the reforming intents of the communist regime then in power. The new institutions that were established by the communist regime beginning in 1980 - that is, after the emergence and subsequent suppression of the Solidarnosc movement-might well have been both a sincere attempt to reform the institutions of government and an attempt to legitimize the regime.

It was M.F. Rakowski, a communist Prime Minister during the martial law period in Poland, who introduced the notion of the socialist Rechtsstaat, directly referring to the original Prussian model. The Constitutional Tribunal, in communist days, interpreted the existing constitution and adhered to the view that constitutional principles were not directly justiciable. Similarly, the Supreme Administrative Court reviewed only procedural issues, not the substance of the cases brought before it. The ombudsman, who was not affiliated with either the communist party or Solidarnosc, decided not to pursue the claims of Solidarnosc members who asserted that their basic rights were abused when the union was suspended in 1981 and then disbanded by the martial law government. Thus, the new institutions of the Rule of Law, introduced by the reformist wing of the communist party, functioned as they were intended, but were not directly involved with issues of basic civic rights and freedoms, the central political controversy within Poland, before 1989.

43. Id. Professor Letowska has noted that, based on Poland's experience, other nations in transition may recognize that "the ombudsman may turn out to be a threat to otherwise unchecked authorities" and avoid or severely limit the institution. Letowska, supra note 37, at 63-64.

44. Approximately $95 \%$ of Poles are members of the Roman Catholic Church. CENTRAL InTELligENCE AGENCY, THE WORLD FACTBOOK 2001 (2001), available at http://www.odci.gov/cia/ publications/index.html.

45. Arcimowicz, supra note 42, at 208. 
Despite some criticism from the Polish anti-communist opposition over the first phase of Professor Letowska's activity, ${ }^{46}$ civil rights advocates generally have made a positive assessment of her term in office. ${ }^{47}$ In the difficult conditions of the final stage of communist rule, almost everything was political, and Professor Letowska certainly defended the rights of individuals, even if she did not necessarily defend the delegalized trade unions and parties. For example, Professor Letowska invoked Article 17 of the Covenant on Civil and Political Rights (recognizing the protection of privacy) in a successful challenge to the customary police practice of ordering hotels to disclose their guests lists. ${ }^{48}$ In addition, she successfully invoked Article 19 of the Covenant (safeguarding the right to one's own opinions) to settle the case of a teacher who challenged the obligation, customary under the communist regime, to attend May Day celebrations. ${ }^{49}$ Before Professor Letowska took up these cases, the Covenant lacked any practical import or application in Poland. When the Covenant was mentioned at all, it was either given lip service by official advocates or invoked in the underground pronouncements of the Helsinki Committee for Defense of Human Rights and similar bodies. A German student of Professor Letowska's activities has noted that

[T]he Polish ombudsman was a factor conducive to creating a new culture of fundamental rights and law.... The way the ombudsman did it, having at her disposal only the brief text of the Constitution, where civil rights have been regulated most superficially, was to adduce the general principles of law borrowed from the Western doctrine of human rights.... The ombudsman addressed her pronouncement, complaints, and opinions to the courts, Constitutional Tribunal, and administrative agencies. She also widely informed the press about her actions and their rationale. By doing this, the Polish ombudsman contributed to the consolidation of the belief that human rights have to be known and included in the work of courts, tribunals, and the administration; and that citizens may invoke those rights when seeking protection. That human rights more and more perceptibly shape the thinking and actions of the Polish establishment today, is largely due to the efforts of the Polish ombudsman. ${ }^{50}$

The volume of the work done by the Polish ombudsmen was tremendous. Professor Letowska received 100,644 petitions; her successor, Professor Tadeusz Zielinski, received 113,002 petitions. The staff of the office consisted of eighty-five people in the first term and 155 people in the second. The first ombudsman accepted 15,987 petitions as cases to pursue; the second ombudsman accepted nearly twice as many-29,856 petitions. Out of these, 10,847 were completed in the first term, with thirty percent being completed to the satisfaction of the claimant $(3,254$ cases $) ; 22,866$ cases were completed in the second term, with twenty percent being completed to the satisfaction of the claimant. ${ }^{51}$ Both holders of the office enjoyed degrees of public popularity to be

\footnotetext{
46. Professor Letowska acted as Poland's Ombudsman from 1988-1992.

47. Arcimowicz, supra note 42 , at 221.

48. Letowska, supra note 37, at 65 (citing Case RPO 40893/89/I).

49. Id. (citing Case RPO 1553/89/I).

50. Id. (quoting GeORg JASTER, DER POLNISCHE BEAUfragte FUER BUERGERRECHTE 113-14, 144-45 (1994)).

51. Arcimowicz, supra note 43, at 108.
} 
envied by politicians; their support levels never went below fifty percent of the respondents in national polls, and towards the end of their respective terms reached heights of about seventy percent. One should take into account the fact that ombudsmen had been set up in Romania (1991), Macedonia (1992), Croatia (1992), Lithuania (1992), Slovenia (1994), Hungary (1994), Russia (1994), Bosnia and Herzegovina (1994), Latvia (1996), Georgia (1996), Uzbekistan (1997), Albania (1999), and the Czech Republic (1999), but only the Polish case has attracted widespread attention based on the extreme usefulness of the institution. ${ }^{53}$

\section{B. The Haunting Spectre of the Socialist Prokuratura}

At some point during the 1970s, the Polish Ministry of Justice announced a strictly controlled "social consultation" soliciting comment on a draft law on social control. The principal author of this essay, as secretary of the Sociology of Law section of the Polish Sociological Association, responded to this request by sending the Ministry a report he had prepared for a small symposium of colleagues, in which he suggested that the government establish an ombudsman office based on the Scandinavian and New Zealand models, with the purpose of defending citizens' rights against the administration. ${ }^{54}$ (The principal author also suggested setting up a Constitutional Court in which citizens who suffered abuse would have a right of direct appeal.) The Ministry's response to this proposal gently suggested that there was no need for an ombudsman because one of the three basic functions of the Procuracy ${ }^{55}$ in the socialist system was to defend the rights of citizens. The author was astonished because he, as most others, had never thought of the institution of the Procuracy in this way. The emblematic Procuracy actually did not perform this function, even though it was formally charged with monitoring all agencies of the socialist State except for the ruling Party, with respect to the legality of their functioning.

Stephen Holmes, in his introduction to a symposium on the functioning of the post-communist procuracy, has observed of this Leninist innovation that

Lenin created what was to become the Soviet procuracy to help impose the Communist Party's will on a reluctant and unruly society. When the Party died, some seven decades later, its progeny was orphaned. After both superficial and substantive changes, the procuracy has survived the end of communism in the "fraternal" countries to which it was eventually exported as well as in Russia itself. But it is the frag-

52. Id. at 25 .

53. A constrasting case is that of Professor Sergei Kovaliov, the Russian ombudsman who was removed from office by the Duma after he had served for only one year, because he dared to criticize the atrocities committed by the Russian armed forces in Chechnya. The case of Professor Kovaliov suggests that the Polish success story is linked to a specific combination of factors. See infra pages

54. Kurczewski, The Rule of Law in Poland, supra note 29, at 188 n.11.

55. The procuracy is an "institution charged with holding public officials accountable and guaranteeing that laws are enforced." Stephen Holmes, Introduction, The Procuracy and Its Problems, 8:1/2 E. EUR. CONST. REV., Winter/Spring 1999, at 76. The office of the procuracy has "no exact parallel in Western legal systems and ... has a much broader mandate than a prosecutor in common-law countries." Id. For a more detailed analysis of the procuracy, see the discussion of the office of the Ombusdman supra in Part II.A. 
ment broken off a defunct system of autocratic power. It drifts disconnectedly, afloat in a wholly unprecedented legal and social context, searching for a new purpose and perhaps a new master. ${ }^{56}$

Although we know very little of how the procuracy works today, the 1999 East European Constitutional Review symposium not only shows that the procuracy "drifts disconnectedly," but also that it drifts in different directions in different countries. ${ }^{57}$ To understand that, one must acknowledge the distinction between the Tsarist despotic concept of the Procuracy- "recycled," as Professor Holmes aptly writes-by Lenin, and the continental European model of procuracy that evolved within the modern context far from the original instrument of the enlightened and absolutist central power. At all events, the national reports presented in the symposium on the functioning of the postcommunist procuracy clearly illustrate both points. They are also illustrated by the various provisions of the countries' respective post-communist constitutions, and by the fact the Polish constitution, for example, despite its impressive length, fails to mention the Procuracy at all. In Russia, its country of origin, the procuracy is still a special organ of the State, while in Poland, the Procuracy functions, as it did before the Second World War, under the Minister of Justice, who is also the Procurator General. ${ }^{58}$ These two models have nothing in common, except for common historical antecedents in the distant past. ${ }^{59}$

Peter the Great, dissatisfied with the unruly Senate, created the office of Procurator General in Russia in 1722 to serve as the "eyes of the monarch," directly responsible only to him, and having the chief supervising authority over both the Senate and the government. Inga Mikhailovskaia has described the duties of the Procurator General under Peter the Great in this way:

The procurator general was charged with representing the czar in the Senate, and he assumed, as well, managerial responsibilities within the Senate. In addition, he was given control over the network of fiskals [tax collectors], the main agents of the Senate. Thus, the procurator general stood between the Senate and its agents and, in time, grew to become the chief supervising authority over both the Senate and the government, which the Senate had previously overseen. The procurator general was obliged to enforce "order and decency during Senate sessions" and to affirm the Senate's decisions; he was also granted the power of legislative initiative. As a result, the procurator general became the key agent of the central government, subservient only to the monarch. ${ }^{60}$

The reforms of Alexander II, who, in 1864, merged the position of procurator general with that of the minister of justice, transformed the procuracy into the agency of criminal prosecution within the general system of courts of justice,

56. Stephen Holmes, Introduction, The Procuracy and Its Problems, 8:1/2 E. EUR. CONST. REV. Winter/Spring 1999, at 76.

57. See Feature: The Procuracy and Its Problems, 8:1/2 E. EUR. CONST. REV., Winter/Spring 1999, at $76-104$.

58. Inga Mikhailovskaya, Russia, The Procuracy and Its Problems, 8:1/2 E. EUR. Const. ReV., Winter/Spring 1999, at 98-104; Zdzislaw Czeszejko-Sochacki, Poland, The Procuracy and Its Problems, 8:1/2 E. EUR. CONST. REV., Winter/Spring 1999, at 90-94.

59. See discussion infra, pages 21-28.

60. Inga B. Mikhailovskaia, Russia, The Procuracy and Its Problems, 8:1/2 E. EUR. CONST. REV., Winter/Spring 1999, at 98, 99. 
and conformed the institution to the general model of the procuracy existing in continental Europe. ${ }^{61}$ With the Russian Revolution, however, soon came the reestablishment of the despotic model of procuracy as the "supreme supervisor of legality." ${ }^{62}$ Professor Mikhailovskaia has observed that "[t]he transformation of the procuracy into a relatively independent, highly centralized, and hierarchical institution took place between 1922 and 1936." ${ }^{63}$ This development was codified in Article 113 of the Stalinist Constitution of 1936, which provided that the "supreme supervisory power over the strict execution of the laws by all People's Commissariats and institutions subordinated to them, as well as by public servants and citizens of the USSR, is vested in the procurator of the USSR." ${ }^{64}$ Article 117 reaffirmed the independence of the procurators from the local authorities and their direct subordination to the procurator general of the USSR, who was nominated by the Central Executive of the Congress of Soviets and was made accountable to the Presidium and to the government. ${ }^{65}$

Within the new constitutional order adopted in 1993, as Professor Mikhailovskaia has said:

[T] he procuracy is assigned a controversial role, because it retains its function as the "supreme and general supervisor of legality." The legal status of procuracy was hotly debated during the constitution-drafting process. Some drafters [including Professor Mikhailovskaia, according to her report] insisted that the office, because it was responsible for prosecutions, belonged to the executive branch, whereas the court should ensure compliance with the law. Others supported the deeply entrenched view that the procuracy was an institution of supreme supervision over legality and thus resisted attaching the office to one of the main branches of power.

A compromise of sorts was finally reached. The article on procuracy (Art. 129) was inserted into the section on the judicial branch. ... The Constitution states that issues such as the procuracy's jurisdiction, structure, and functions were to be determined by a special law (Art. 129.6).

In this way, the problem was avoided so that the drafters were not required to deal with it in the text of the Constitution itself. The answer was soon given, however, in the federal law on the procuracy which was enacted in 1995 and "preserve[s] the Soviet premise that the procuracy supervises the implementation of laws." ${ }^{67}$ Pursuant to this law, the duties of the Procurator are: (1) general

61. In addition to conducting prosecutions, the procurators were to supervise preliminary investigations conducted by court investigators. They also were authorized to arrest suspects and release detained persons, and could order additional investigation even if an investigator considered an investigation complete. Thus, the supervisory role of the procuracy was replaced by a prosecutorial role. Id.

62. Id.

63. Id. at 100. In 1922, the Russian procuracy was established within the People's Commissariat of Justice. Its functions were: "(1) to monitor, on behalf of the state, all governmental agencies, economic organs, public associations, private organizations, and individuals, and to prosecute officials who violated the law and to scrutinize the validity of their decisions; (2) to directly supervise the investigative agencies, such as the militia and the OGPU (later known as the KGB); (3) to conduct prosecutions in court; and (4) to supervise the penitentiary system." Id.

64. Id. (citing the STALIN CONSTITUTION of 1936, art. 113).

65. $I d$.

66. Id. at 101 .

67. Id. 
supervision of legal compliance by federal ministries, legislative assemblies, and the executives of the member states of the Russian federation, organs of self-government, and the army; (2) supervision of the work of the police and criminal investigation agencies; (3) monitoring of the penitentiary system and detention centers; (4) prosecuting criminal cases; and (5) coordinating efforts to fight crime. ${ }^{68}$ In addition, however, the procuracy is also charged with supervising the "observance of human and civil rights." According to Professor Mikhailovskaia, this innovation, "which reflects a desire to reform the judicial system, is of dubious significance," because there is little difference between "a violation of law or an illegal action by an official ... [and] a violation of civil rights, if the latter is the result of the former." It appears that, "[in] the case of supervision of human and civil rights, a procurator's purview extends to commercial and non-commercial organizations," whereas, with respect to the procurator's duties concerning compliance with law, the procurator focuses on the activity of government bodies. ${ }^{71}$ The practical functioning of the procuracy is unclear, especially because the relationship between the Ministry of Interior and the procuracy remains ambiguous. Both departments have their own investigators in criminal cases, and the procuracy's investigators are usually unable to complete an investigation without assistance from the Ministry of the Interior. Moreover, it is the police who provide most of the evidence that is presented at trial. $^{72}$ Professor Mikhailovskaia has observed that

In general, legal specialists seem to agree that the procuracy is a necessary institution. This may be explained by the Soviet mentality of the majority of lawyers, the conservative character of duma, and the procuracy's very effective lobbying efforts during the drafting of the laws related to its office. Despite its exaggerated powers, the procuracy is not a key player in contemporary Russian politics. After the events of 1993, it remained neutral in the political fight between the branches of government; the position it maintains is passive. Its priority is to preserve its own institutional interests, which are safeguarded by both the executive and the legislative branches.

That situation had changed by 1998, when Procurator General Yuri Skuratov was aggressively investigating high-ranking officials in President Yeltsin's administration. ${ }^{74}$ Professor Holmes has remarked that the battle between Procura-

68. Id. Significantly, "the 1995 law ... notably fails to grant procurators in the courtroom the right to supervise the legality of court proceedings—a right that procurators had possessed before 1992." Id.

69. Id.

70. Id. at 102 .

71. Id.

72. Id. at 104 .

73. Id.

74. The battle between Procurator General Yuri I. Skuratov and President Yeltsin's administration began in 1998 when Skuratov started investigating corruption within President Yeltsin's inner circle, taking aim at such important figures as Sergei Durbin (former central-bank chairman) and Pavel Brodin (the head of Yeltsin's personal office). See Holmes, supra note 57, at 78. Skuratov publicly alleged that, during the financial crisis in the summer of 1998, major figures around Yeltsin were involved in illegal capital exports, gross embezzlement, rigged privatizations, illegal banking activities, and illegal trading in government securities. Id. Skuratov also initiated an investigation into bribes allegedly paid to Kremlin officials by a Swiss corporation, Mabetex, leading to allegations that $\$ 1$ million was channeled to Yeltsin's family through Pavel Bordin and that Yeltsin's family were given credit cards that were paid by the president of Mabetex. See Celestine Bohlen, Russian Says He Has Proof Bribes Were 
tor General Skuratov and President Yeltsin's administration was political in nature, involving the procuracy as "a weapon in the ongoing struggles between the legislative and the executive, and between the center and the regions." 75 As Professor Holmes also remarks, it would be "a great irony if the procuracy, an office created to enforce the writ of the center on the periphery, were now captured by the regions and used to weaken the grip of Moscow on the rest of the country." ${ }^{, 76}$

In Romania ${ }^{77}$ and Hungary, ${ }^{78}$ procurators are still expected to defend "citizens' rights and freedoms." In Poland, however, the amendments made to the communist constitution on December 29, 1989, repealed all provisions relating to the procuracy and "introduced a new article providing that the procuracy is the guardian of the rule of law charged with administering the prosecution of crimes." 79 This revolutionary change left the Office of the Procurator General to be administered by the Minister of Justice, acting pursuant to specific laws that might be enacted from time to time. ${ }^{80}$ Zdzislaw Czeszejko-Sochacki, the reporter on Poland for the East European Constitutional Review symposium on the procuracy, probably based on sympathy towards the previous model, criticized these changes (as well as others enacted in 1996) as "lack[ing] uniformity" and made without "any logically coherent model." as Professor Czeszejko-Sochaki observes, during the debate on the new Polish constitution, which extended from 1993 to 1997, several drafts were presented which would have re-established the procuracy as an element of constitutional design:

Some participants in the constitution-making process proposed including the procuracy in the chapter on the judicial branch, while others envisaged its separation from the judiciary and inclusion in the chapter devoted to law-enforcement institutions. From an organizational point of view, the question was whether the procurator

Paid to Kremlin, N.Y. TIMES, Aug. 31, 1999, available at 1999 WL 30479645. The battle between Skuratov and Yeltsin took an interesting twist when, on the night that the upper house of Parliament was to vote on Skuratov's dismissal, a television news program on a Government channel broadcast a secretly filmed tape of a naked Skuratov in bed with two naked young women. Celestine Bohlen, Yeltsin's Inner Circle Under Investigation for Corruption, N.Y. TIMES, Mar. 24, 1999, available at 1999 WL 9876528. During 1999, Yeltsin made three attempts to fire Skuratov, but the upper house of the Parliament rebuffed each attempt. See Celestine Bohlen and Michael Gordon, Lawmakers Turn Back Another Attempt by Yeltsin to Dismiss His Chief Prosecutor, N.Y. TIMES, Oct. 14, 1999, available at 1999 WL 29282800. It was only after the election of President Putin that Skuratov was finally dismissed on April 19, 2000. Celestine Bohlen and Michael Gordon, New Victories in Parliament Show Strong Hand of Putin, N.Y. TIMES, Apr. 20, 2000, available at 2000 WL 21240996.

75. Holmes, supra note 56, at 78.

76. Id. at 79 .

77. CONSTitutia Romaniei [CONSTITUTION] art. 130.1.

78. HUNG. CONST. art. 51.1.

79. Zdzislaw Czeszejko-Sochacki, Poland, The Procuracy and Its Problems, 8:1/2 E. EuR. CONST. REV., Winter/Spring 1999, at 89, 91. Article 64 of the Polish Constitution of July 22, 1952, provided that "the procurator general protects the justice system, guards public property, and ensures respect for the law, in particular, he supervises "crimes against the state." Id. at 90. During this period, the procuracy was overseen directly by the Council of State, and indirectly by the Sejm. Id.

80. Id. at 91 .

81. Id. 
general should report directly to parliament or to the executive (as does the minister of justice who also serves-both then and now-as procurator general) ....

The [relevant constitutional] subcommittee eventually agreed to recommend to the Sejm that it either leave the constitutional provisions regarding the procuracy's responsibilities intact or delete the provisions in their entirety and thus eschew the issue of the "constitutionalization" altogether.

The subcommittee's proposals were discussed by the Constitutional Committee on September 5 and 26, 1995. During the debates held on September 5, the majority of MPs [members of Parliament] rallied behind the view that the procuracy was not a constitutional institution....

The same pattern of argument emerged during the discussions on September 26. While [post-Communist Minister of Justice] Jaskiernia and legal experts supported the procuracy's constitutionalization, the majority of MPs were clearly opposed. U1timately, the committee voted 20 to 8 , with one abstention, against including any provision concerning the procuracy in the Constitution. When the issue came up for a vote in the Sejm, the deputies followed the committee's recommendation and blocked attempts to introduce the procuracy into the constitutional text. An amendment stipulating that the current minister of justice would act as the procurator general also failed (302 votes were needed for two-thirds majority support; 227 deputies voted in favor and 215 against, with 10 abstentions). ${ }^{82}$

The reporter on Poland for the East European Constitutional Review symposium, who is affiliated with the post-communist orientation in politics, points to the fact that this decision left the concrete shape of the procuracy in the hands of Parliament, and that possible stability in the structure of the procuracy was lost because Parliament can easily amend the laws dealing with procuracy with every shift in the balance of power in Parliament. ${ }^{83}$ On the other hand, it can be argued that this resolution is eminently sensible, given the fact that the issue is intensely controversial and that a fixed constitutional position, once adopted, would be more difficult to change. In effect, the position of procurator in Poland is now a sort of civil servant, subordinated to the Minister of Justice, and lacking the various privileges allocated to the judiciary. The opposite was true during the communist period, when procurators were independent of the executive, better paid than judges, and charged with the control of the legality of the state. In this sense, Professor Czeszejko-Sochacki is correct in noting that "[p]olitical practices before 1989 shaped prevailing attitudes towards the procuracy more than any other factor." ${ }^{\prime 4}$ In pointing to the less exalted model of procuracy adopted in 1989, Professor Czeszejko-Sochacki emphasizes the danger of political influence on the procuracy, and writes as if political influence had been the only weakness of the old Peter the Great/Lenin model. Indeed, there is a note of resignation in his final judgment that "even if the 'courtroom' procuracy model is adopted ... it will still be necessary to establish the structural conditions securing the political neutrality of the procurator's office. ${ }^{\prime 85}$
82. Id. at $91-92$.
83. Id.
84. Id. at 94 .
85. Id. at 94-95. 
In truth, the omnipotent Russian model of procuracy as the "ruler's eyes" had been crushed in Poland before 1989. The legitimizing myth that the procurator would act in defense of the rights of citizens-a duty that socialist procuracies never took seriously-also had disappeared as the procuracy's power waned. These developments are particularly interesting when compared to the experience in countries such as Romania, Hungary, and Bulgaria. For example, "the Romanian procuracy has remained relatively untouched by the institutional transformations unleashed after 1990." ${ }^{86}$ Not only does the institution retain many of the powers it enjoyed under the dictatorship, but it was true as late as 1999 that "most of Ceaucesu's prosecutors still hold the positions they occupied before." along the organizational and operational socialist lines inherited from the old regime." ${ }^{\prime 8}$ As part of the Hungarian Roundtable Talks of 1989, the reformminded communists, in the "last major attempt to preserve socialist values and the existing political regime while introducing a new "model," ${ }^{\prime \prime 9}$ presented three possible versions of the procuracy's legal status. With minor modifications, however, the procuracy of the old regime has subsequently remained entrenched, despite all contrary efforts by the subsequent democratic governments. ${ }^{90}$ Finally, as to the independence of the procuracy, it would be worthwhile to Polish defenders of the idea to study the negative experience of the procuracy in Bulgaria, where the 1991 constitution abolished the system of the old regime, but included the procuracy within the ranks of the judiciary, thus keeping the procuracy immune from outside monitoring and control. ${ }^{91}$

\section{Constitutional Courts}

The idea of constitutional courts is relatively new in Central and Eastern Europe; they did not exist in the region prior to the imposition of the communist regime, and were therefore alien to the local institutional cultures of these nations. Ion Muraru, the president of the Romanian Constitutional Court, has written:

In our country, in the debates in the Constituent Assembly, it was hard to convince even the lawyers that we needed a distinct authority of this sort. They said: "In 1923, the High Court of Cassatia and Justice, which is similar to the Supreme Court today, was responsible for this, so let's go back to the way things used to be." Then we ex-

86. Monica Macovei, Romania, The Procuracy and Its Problems, 8:1/2 E. EUR. CONST. REV., Winter/Spring 1999, at 95, 98 .

87. Id.

88. Istvan Szikinger, Hungary, The Procuracy and Its Problems, 8:1/2 E. EUR. CONST. REV., Winter/Spring 1999 , at 85 .

89. $I d$. at 89 .

90. Id. at 90 ("And so, for all the change, and effort of achieving further change, the basic structure of the procuracy remains as it was in the past, before 1989. In large measure, the past is still with us.").

91. Zdravka Kalaydjieva, Bulgaria, The Procuracy and Its Problems, 8:1/2 E. Eur. Const. Rev., Winter/Spring 1999, at 79, 80-81. 
plained that, in Western Europe, things were no longer the way they were in 1923. The present Constitutional Court was created out of these debates and discussions.

Even in Poland, where lawyers from the small satellite Democratic Party (to which Prime Minister Hanna Suchocka and Speaker of the Senate Alicja Grzeskowiak belonged) had pressed for the establishment of a constitutional court in the last decades of communist rule, there was a faction of lawyers who took the view that a constitutional court was unnecessary because the Supreme Court is the proper court to decide constitutional matters. ${ }^{93}$ In the main, constitutional courts were established to ensure the continuation of the new transitional constitutions usually negotiated between major actors, and to secure the objectives of those settlements, such as the nomenklatura giving up their exclusive monopoly of power.

Of the constitutional courts in the region, the Hungarian Court has won the highest praise from the international community of observers. As in Romania and other countries in the region, the very idea of a constitutional court was alien to the Hungarian constitutional tradition. ${ }^{94}$ As created, however, the Court has authority to review acts of Parliament and other legal rules, to review unconstitutional omissions by the legislature, and to hear constitutional complaints alleging the violation of individual constitutional rights as the result of the application of an unconstitutional law. ${ }^{95}$ The Court's decisions are final, without appeal, and are binding on everyone. ${ }^{96}$ If a legal norm is found to be unconstitutional, the Court declares the norm to be wholly or partly null and void. ${ }^{97}$

In order that legislative restrictions on basic rights should not become autocratic, the Constitutional Court has stated that the following conditions must be met. In order to introduce a restriction there must be some very strong compelling reason, such as enforcement of another basic right. This objective must be proportionate to the injury to the basic right brought about by its restriction. The legal restriction must be adequate for attaining its objective.... These principles can be seen most clearly in a decision of the Constitutional Court (20/1990.X.4), in which the Court abrogated a provision in a law which compelled the leaders of parties and of social organizations to provide information about the extent of their personal assets. The court declared that this statutory provision was against the Constitution because it restricted the essential contents of the right to protect one's private secrets and personal data.

The right to file an individual constitutional complaint in Hungary is restricted, as it may be heard by the Constitutional Court only after all other legal remedies have been exhausted, and even then only if the individual's rights have been violated by the application of an unconstitutional legal provision. In

92. Interview by Alina Mungiu-Pippidi with Ion Muraru, President of Romanian Constitutional Court, 6:1 E. EUR. CONST. REV., Winter 1997, at 78-83.

93. Interview by Jolanta Kroner with Judge Janusz Trzcinski, Deputy President of Constitutional

Court, Trybunal ponad polityka [Court Above Politics], RzECZPOSPOLITA, Dec. 12, 1994.

94. Halmai, supra note 18, at 162.

95. Id.

96. $I d$.

97. Id.

98. Halmai, supra note 18 , at 163. 
contrast to the German Constitutional Court, the major part of whose caseload consists primarily of individual complaints, individual complaints comprise less than one percent of the total number of potential claims in Hungary's Constitutional Court. As Gabor Halmai has noted, the judges of the Hungarian Constitutional Court have tried to give substance to this unused institution of the individual complaint more than once in the past few years, but the extent of their authority is unclear. In the very first decision intended to serve as a precedent in this area, the Constitutional Court annulled a judgment in an actual case, ${ }^{99}$ but this decision proved controversial and was rightly criticized as a usurpation of the authority of the Supreme Court: "The President of the Supreme Court referred to Article 70/K of the Constitution, according to which all lawsuits concerning the violation of the fundamental rights belong to the jurisdiction of ordinary courts." Thus, as Judge Halmai has noted, "[a]lthough the judge who delivered the majority opinion of the Constitutional Court argued that there was no other way of giving remedy in the particular case than to annul the verdict, no such powers are to be found in the Act on the Constitutional Court." 101 Here experts and the President of the Constitutional Court agree, however, that these provisions should be changed at the earliest opportunity. ${ }^{102}$

Another perceived weakness of the Hungarian Constitutional Court rests in the Court's unusual authority to deliver abstract "advisory opinions." ${ }^{103}$ The court is authorized, if such a request is made by specified bodies, to interpret the Constitution in an abstract manner, without reference to the existence of a particular case or controversy. Thus, Judge Halmai has written:

The experience of the first six years proved that these "advisory opinions" were those that were most often required by political forces so as to justify their own claims. Recently, the Court itself extended its jurisdiction into non-desirable directions. What I have in mind, primarily, is the determination of the constitutional content of laws, that in a number of occasions-as for example in case of the constitutional investigation of economic stabilization laws-replace the repeal of the contested by-laws. Since these interpretations were placed in the operational part of decisions by the Judges, they apply with a compulsory force to everybody without the Constitutional Court bearing this jurisdiction.

The President of the Hungarian Constitutional Court takes a different view and emphasizes that there are two sides to this activism:

Simply think about the prerogatives derived from an abstract interpretation of the Constitution: abstract control of constitutional standards, which is a kind of advisory opinion, but with binding force, preliminary review of legislative drafts, and, most im-

99. Gabor Halmai, Separation of Power-Social Rights-Judicial Review. The Polish and Hungarian Cases, in Constitution-MAKING Process 83, 89 (Miroslaw Wyrzykowski ed. 1998) (discussing Decision No. 57/1991, November 8).

100. Id.

101. Id. (footnote omitted).

102. Id.

103. In the American system, Article III of the Constitution precludes federal courts from granting advisory opinions, Muskrat v. U.S., 219 U.S. 346, 360, 31 S. Ct. 250, 255 (1911), but the constitutions of some states permit the courts to provide such opinions. See, e.g., MA. CONST. art. 2; ME. CONST. art. 6, $\S 3$.

104. Halmai, supra note 100 , at 89 . 
portantly, the fact that everyone has standing to submit a petition about any law, without being involved or interested in an actual case. This unrestricted standing for "abstract norm control" is unique in the world. Probably the opposition, in 1989, thought it necessary to put the still-ruling single party under strict supervision. That authorization raised the danger of direct political involvement, and the Court already seriously restricted its own prerogatives in this area in 1990. Essentially, we canceled preliminary constitutional review by introducing some technical preconditions. A claim can now be submitted only before the final vote in Parliament. . . .

Activism can mean different things. We always stress that we are activists in certain areas, namely, concerning fundamental rights, where the Court does not hesitate to decide "hard cases." But we are self-restrictive concerning the problems related to the political structure.... It is quite obvious that the Court should interpret the existing constitutional standards on an abstract level, which means that when we apply the standards to concrete cases, we reinforce, clarify, and sometimes extend constitutional principles. By the way, the Court has never used the phrase "invisible constitution." I used it only once, in 1990, in a concurring opinion. The only thing I sought to clarify with the phrase was that, when the Court makes judgments on the bases of legal and constitutional principles, we must adhere to the general concept of constitutionalism, regardless of the interests and aims of everyday politics. Do not forget that, at that time, Parliament was changing the Constitution almost every two weeks! Later, the concept [of "invisible constitution"] changed slightly, and meant that the Constitution was the text itself, supplemented by the interpretations developed in the decisions of the Court. These two, together, create the Constitution or rather the constitutional reality (as the Germans say).... Let me stress that we have never gone too far, and one of the main sources of confusion is that critics and politicians are ignorant of other constitutional courts. When we struck down several provisions of the illfamed Bokros austerity-package in 1995, everyone cried that congressional courts in the West never intervene in economic affairs. This is simply false.

What President Solyom took as the ordinary costs of implementing the constitution, for some observers-like Judge Halmai, ${ }^{106}$ and Professors Sajo ${ }^{107}$ and Schwart $\mathrm{z}^{108}$ - went too far in politicizing the Constitutional Court. Jiri Priban has written in a similar vein of the Czech Constitutional Court. ${ }^{109}$

The Polish Constitutional Court stands at the opposite pole. Established in 1985, in what was still communist Poland, it was the first court of its kind in the region of Central and Eastern Europe. Initially, its powers were restricted. ${ }^{110}$ Decisions on the unconstitutionality of legislative acts were not binding, and

105. Andras Mink, Interview with Laszlo Solyom, President of the Hungarian Constitutional Court, 6:1 E. EUR. CONST. REV. Winter 1997, at 71, 72-73.

106. Halmai, supra note 100 , at 89.

107. Andras Sajo, How the Rule of Law Killed Hungarian Welfare Reform, 5:1 E. EUR. CONST. REV., Winter 1996, at 1, 31-41.

108. Hermann Schwartz, Constitutional Courts: Of Politics, Law and Justice, in Constitution-MAKing Process 71, 81 (Miroslaw Wyrzykowski ed., 1998).

109. Jiri Priban, The Constitutional Court of the Czech Republic and a Legal-Philosophical Perspective on the Sovereignty of the Law, in HUMAN RIGHTS IN EASTERN EUROPE 135, 140 (Istvan Pogany ed., 1995).

110. Professor Andrzej Zoll, Chief Justice of the Constitutional Court, observed in 1997 that the Court has a more restricted jurisdiction and fewer powers than other constitutional courts that were created later in the region: "The Tribunal, for example, cannot review decisions that are more than five years old, and this limitation precludes changing many regulations from the communist era, even though they do not correspond to Poland's new democratic rule-of-law system (demokratyczne panstwo prawa)." Irena Grudzinska-Gross, Interview with Professor Andrzej Zoll, Chief Justice of the Polish Constitutional Tribunal, 6:1 E. EUR. CONST. REV., Winter 1997, at 77. 
parliament could reject any such decisions by a two-thirds vote. This power, which amounted to a "legislative veto" over the constitutional judgments of the Constitutional Court, was pursued by Parliament most fiercely and successfully in the case of decisions concerning social and economic rights, which, if implemented, would have been costly to the government. Parliament's use of its power to override these judicial decisions thus enhanced the efficacy of the policies known as "Balcerowicz's shock therapy," which permitted Poland to attain the greatest speed of economic development after the universal economic decline that accompanied the disintegration of the old command economy. ${ }^{111}$ Like the Hungarian Constitutional Court, the Polish Constitutional Court also was not designed to hear constitutional complaints of ordinary citizens. ${ }^{112}$ In general, the Constitutional Court was created to offer authoritative constitutional expertise in the complex process of legislating reforms. ${ }^{113}$ It is only since the adoption of the Constitution of 1997 that the role of the Constitutional Court has changed dramatically. ${ }^{114}$ The most important change is the finality now attributed to its decisions concerning the constitutionality of legislation. ${ }^{115}$ Because this change significantly affected Parliament's newly regained sense of sovereignty, the effective date of this change was delayed until two years after the Constitution had been ratified by national referendum. ${ }^{116}$

Professor Osiatynski, taking pride in his participation in the final drafting of the Polish Constitution of 1997, has stressed the importance of the provisions permitting the direct enforceability of rights:

The leading provision, Article 8.2, holds that the provisions of the Constitution are directly effective. Articles 77 through 80 provide for the right of redress when rights and freedoms have been violated, the right of judicial protection, the right to appeal a court decision, the right to address the ombudsman, and most importantly, the right of constitutional complaint....

The introduction of judicial complaint and constitutional complaint is equaled with a departure from the tutelary model of the protection of rights only via the media or the ombudsman.... Now, every person can address personally the state and its officials—not as a subject, but as an equal. ${ }^{117}$

Professor Poplawska has been more skeptical about the practical significance of this achievement, saying:

The complaint concerning a constitutional infringement is treated as a subsidiary means of protection of the rights guaranteed by the Constitution since the subject, whose basic rights have been infringed by application of a legal instrument incompatible with the Constitution as the legal basis for the judgment, may only submit the

111. See, e.g., Ash, supra note 25 , at 372 .

112. Mark F. Brzezinski, Constitutionalism Within Limits, The New Constitutional Courts: Poland, 2:2 E. EUR. CONST. REV., Spring 1993, at 38, 40.

113. Id.

114. POL. CONST. of 1997, arts. 188-97, in CONSTITUTIONAL ESSAYs 405-75 (Miroslaw Wyrzykowski ed., Institute of Public Affairs 1999).

115. Id. at art. 190.1

116. Id. at art. 239.1.

117. Wiktor Osiatynski, A Brief History of the Polish Constitution, in CONSTITUTIONAL EsSAYs 37, 53-54 (Miroslaw Wyrzykowski ed., 1999). 
complaint after having used other methods of appeal and means of protection of his/her rights (completion of the instance procedure). A complaint concerning a constitutional infringement may only be submitted if the court's judgment, decision or another administrative adjudication infringes a constitutional right of the appellor, but only if the applied legal provision is contrary to the Constitution.

Therefore this institution is also subsidiary in relation to other procedures of enforcing cohesion and compliance with the Constitution of the whole legal system. ${ }^{118}$

Professor Popowska might also have mentioned another obstacle, which is the need to be represented by counsel when vindicating constitutional rights-a factor that may easily discourage potential claimants. ${ }^{119}$ In any event, she further observes that "[i]t may be feared ... that its scope will prove to be disproportionately narrow as compared with the social expectations which arose, chiefly, due to unfamiliarity with law." ${ }^{120}$ Because popular expectations may well outstrip reality, Professor Poplawska expects that the Constitutional Tribunal will experience a loss of popularity within society.

Professor Schwartz, while making an overall positive assessment of the new Central Eastern European constitutional courts, has remarked that there is some inevitable risk of political involvement by the constitutional courts in question. ${ }^{121}$ Professor Schwartz has observed that:

\begin{abstract}
Separation of powers among the legislature, executive and judicial branches is a fundamental aspect of all new constitutions in the region, and the obligation to resolve separation of powers issues between the legislature and the executive is something imposed on all the Constitutional Tribunals. Yet by definition, the separation produces systematic and continual conflict over power between these two branches, especially in these early years when very little is settled and where the constitutions are not altogether clear.... Nevertheless, these separation of powers issues are a necessary part of a constitutional court's jurisdiction, no matter how hard or controversial they are. $^{122}$
\end{abstract}

In addition, constitutional courts in the region are often given responsibility for functions that are apt to create tensions beyond those that are simply inevitable because of separation of powers and judicial review, such as those which come from validating elections or delivering abstract interpretations of statutes at the request of political actors. Even more serious problems arise, however, when judges of the constitutional courts are tempted to enter directly into public controversies, as when the Russian Constitutional Court ended up taking part in the political struggle in 1993 between President Yeltsin and the Parliament. ${ }^{123}$

118. Ewa Poplawska, The "Constitutionalization" of the Legal Order, in CONSTITUTIONAL EsSAYS 71, 84 (Miroslaw Wyrzykowski ed., 1999).

119. Law on the Constitutional Court of Aug. 1, 1997, Art. 48 in LAW Journal, RePUBLIC OF POLAND, No. 102, item 643.

120. Poplawska, supra note 118 , at 84 .

121. Schwartz, supra note 108 , at 75.

122. $I d$. at 78 .

123. Id. at 79, 81. In 1993, President Yeltsin and the Parliament were engaged in a power struggle over the issue of presidential or parliamentary supremacy. President Yeltsin staked his claim to supremacy on the fact that he was the sole official with a direct mandate from the Russian people, whereas the Parliament based its claim on the Constitution, which declares them the highest legal authority in the land. Serge Schmemann, The Fight to Lead Russia: Lacking a Keystone for Legitimacy, Yeltsin and Foes Wage a Struggle With Few Rules, N.Y. TIMES, Mar. 13, 1993, at A1. The chair of Rus- 
Professor Schwartz has particular praise for the Slovak and Bulgarian constitutional courts for their performance as defenders of human rights. ${ }^{124}$ Other constitutional courts in the region could also be added to his list. On the whole, constitutional adjudication has served as the major institutional bulwark in the region against the encroachments on human rights from governments and legislatures.

III

\section{CULTURE OF Rights}

There is general agreement that basic freedoms and liberties cannot be implemented if they are not surrounded by a general culture of rights. ${ }^{125}$ One of the first liberal law-reformers in this region, the great Polish-Russian scholar Leon Petrazycki, who lived from 1867 to 1931, observed while developing his original theory of legal pluralism that proper legal socialization is impossible without formation of a legal psyche that inculcates an appropriate balance of rights and duties. ${ }^{126}$ Petrazycki observes that a personality is legally undeveloped or underdeveloped when it is devoid of self-assertion and has been taught only obligations toward superiors who may or may not, at their whim, repay in arbitrary satisfaction of the individual's needs and wishes. ${ }^{127}$ To this legally undeveloped, or underdeveloped, personality Petrazycki gives the name anima servilis. ${ }^{128}$

There are many reasons to be pessimistic about the development of a culture of rights in the post-communist world. One must remember that in this area, east of the river Elbe, serfdom kept most of the farming population in legal dependency on their masters well into the nineteenth century. It is also significant that Russia, perhaps the most important of all the great powers that have dominated the area since the fall of the Polish-Lithuanian Commonwealth,

sia's Constitutional Court, Valery D. Zorkin, interjected himself into the dispute, first by trying to arrange a compromise between Yeltsin and the Parliament, and later by consistently supporting the Parliament in its claim to supremacy. Celestine Bohlen, Struggle in Russia: Yeltsin, In Speech, Appeals for Calm After "Nightmare," N.Y. TIMES, Oct. 7, 1993, at A1. Zorkin eventually resigned under pressure from President Yeltsin. Id.

124. H. Schwartz, The New Courts: An Overview, 2:2 E. EUR. CONST. REV., Spring 1993, at 30, 31.

125. Charles R. Epp has recently argued that the existence of effective advocacy groups is critically important to the protection of rights. CHARLES R. EPP, THE RIGHTS REVOLUTION: LAWYERS, ACTIVISTS AND SUPREME COURTS IN HISTORICAL PERSPECTIVE 6 (1998). Based on his study of civil rights litigation in the United States, India, Britain, and Canada, Professor Epp concluded that judicial leadership is not itself the catalyst for change, as other scholars have posited, but that "sustained judicial attention and approval for individual rights grew primarily out of pressure from below, not leadership from above." Id. at 2. Moreover, "[t] his pressure consisted of deliberate, strategic organizing by rights advocates," which "became possible because of the development of support structures for legal mobilization, consisting of rights-advocacy organizations, rights-advocacy lawyers, and sources of financing, particularly government-supported financing." Id. at 2-3.

126. ANDRZEJ WALICKI, LEGAL PHILOSOPHIES OF RUSSIAN LIBERALISM 260 (1987).

127. Id. at 258, 262; LEON PETRAZYCKI, O NAUCE, PRAWIE I MORALNOSCI. PISMA WYBRANE [ON SCIENCE, LAW AND Morals: SElected Works] 258 (J.Licki and A. Kojder, eds., Polish Scientific Publishers 1985).

128. WALICKI, supra note 126, at 258; PETRAZYCKI, supra note 127, at 259. 
experienced only one brief episode of experimentation with parliamentary government, from 1906 to $1914 .{ }^{129}$ Totalitarian and authoritarian governments soon took over after the constitutional monarchies were abolished by the revolutions of 1917. The anima servilis identified by Petrazycki was elevated to the model of sacrifice for Party, Nation, and State, and became the cornerstone of the soviet and communist legal systems. ${ }^{130}$ Rights were officially declared, but their enjoyment was left to the arbitrary will of rulers who situated themselves above the law. ${ }^{131}$ The everyday enforcement of law was reduced to the enforcement of

129. Medushevskiy has written that: "Necessity of passage from absolutism to the legal state ('pravovoie gosudarstvo') began to be apprehended already in the 18th, and especially in the 19th centuries (in proposals of the political and constitutional transformations), but the problem was in fact put as late as in the decisive stage of the first Russian revolution." A.N. MEDUSHEVSKIY, DEMOKRATIYA I AVTORITARISM: ROSSIYSKIY KONSTITUCIONALIZM V SRAVNITEL'NOY PERSPEKTIVE [DEMOCRACY AND AUTHORITARIANISM: RUSSIAN CONSTITUTIONALISM IN COMPARATIVE PERSPECTIVE] 451 (1998).

130. It was because of this emphasis on "duties" under Soviet-style constitutions that the inclusion of duties in the new constitutions of Eastern and Central Europe was considered by drafters of these constitutions, and it was also because of that legacy that the inclusion of such duties was considered controversial. In a paper delivered in 1996 concerning the draft Polish constitution being considered at that time, Wojciech Sadurski wrote:

[The inclusion of a constitutional duty to comply with statutory "duties"] has its costs. For one thing, it diminishes the libertarian flavor and introduces a statist rhetoric to the Constitution: The symbolic message is that while the state has some duties toward its citizens, nevertheless the citizens have duties not just to each other but also to the state. This message emerges from Art. 67: "Loyalty and faithfulness to the Republic of Poland shall be the duty of every Polish citizen." The duty thus described is almost fully indeterminate, but it adds a statist flavor to the text. Secondly, the inclusion of duties alongside rights may be seen as implying that the enjoyment of one's rights is conditioned upon the performance of one's duties. It is not stated explicitly, but this may be one way of interpreting the reason behind including duties in the Constitution (which otherwise, as just suggested, are redundant). But such an implication is, of course, an anathema for a liberal theory of citizens' rights: No one surrenders his or her rights (certainly, no one surrenders all one's rights) by not discharging his or her duties. The opposite view may be seen as a residue of the old, Communist approach to constitutional law, which took delight in emphasizing the so-called interrelation of "rights" and "duties."

Wojciech Sadurski, The Meaning of Constitutional Rights in Liberal Democracies, in CONSTITUTIONMAKING PROCESS 39, 52 (Miroslaw Wyrzykowski ed., 1998).

131. An entire chapter of the Soviet Constitution of 1936 was devoted to setting down the "Fundamental Rights and Duties of Citizens." Christopher Ruder has written:

Under Stalin, Soviet citizens were afforded individual economic rights on paper after the adoption of the 1936 Constitution, but enforcing these rights was ineffective because of the lack of strong judicial enforcement and the extreme centralization of power. As a result, both Stalin and Soviet lawmakers often ignored the Constitution, and although it purported to establish a formal legal system, the Constitution was always subject to abrogation under the auspices of its socialist purpose.

Christopher T. Ruder, Comment, Individual Economic Rights Under the New Russian Constitution: A Practical Framework for Competative Capitalism or Mere Theoretical Exercise?, 39 ST. LOUIS U. L.J. 1429, 1437 (1995).

Even as late as the Soviet Constitution of 1977, rights were officially declared but their enjoyment was left to the arbitrary will of the Party leaders. For example, Article 50 of the 1977 Constitution guaranteed the freedom of speech, press, assembly, and demonstration. However, Professor Samuel Hendel has noted:

$[\mathrm{T}]$ he very provision granting these rights imposes the limitation that they must be exercised "in accordance with the interest of the people and in order to strengthen and develop the socialist system." And what is more, a new article (number 39) in the 1977 Constitution requires that "enjoyment by citizens of their rights and freedoms must not be to the detriment of the 
the duties which the citizen was thought to owe to the Party-State. ${ }^{132}$ To the extent that rights were acknowledged, their enforcement was at the unbridled discretion of the administrators, rather than through the courts or other disinterested decision-makers acting on principle. ${ }^{133}$

In Russia, some interesting social science survey research was undertaken in the early years of the democratic regime. In this survey, a representative sample of Russian citizens was asked about the importance of various rights and to whom one would appeal in the case of their abuse. ${ }^{134}$ In 1994, at least eightynine percent of those polled mentioned, as important or very important, the right to legal protection, social and economic rights (for example, health care, maternity care, pension, and free education), the right to personal safety and the inviolability of one's own property, and the right to fair compensation for one's labor. ${ }^{135}$ Ranked second were the right to be protected against arbitrary job dismissal and the right to free choice of residence $(70 \%$ and $63 \%$, respectively); next came the right to private property (54\%) and the right to receive and distribute information (49\%). Only thirty percent ranked the right to have any or no religious beliefs as important or very important, and the right to participate in the activities of any political party or movement was judged to be important or very important by only twenty-three precent of the respondents. Only seven percent of the respondents perceived the inclusion of personal rights and freedoms in the Constitution as a positive change..$^{136}$

This survey showed that political freedoms were rarely seen as important, whereas material well-being was the most important value for almost half of the respondents, with personal safety ranked next. Although the prevailing mass of Russians rejected dependence on the State as an answer to their problems, onethird accepted restrictions upon human rights if the interest of the State so required, and a majority (54\%) thought that "a good and tranquil life depends not on the number of rights but on the extent of state care," ${ }^{137}$ with only a minority $(27 \%)$ disagreeing with that view. ${ }^{138}$ In another forced-choice question, people were asked to choose whether a great danger to society was posed by "con-

\footnotetext{
interest of society...." In practice, the judgement of which freedoms serve the "interests" of the people or are "detrimental" to their interests, or help strengthen the socialist system, or enhance the power and prestige of the Soviet state, rest, of course, not with the people themselves, but with the party or, more accurately, with the Party leaders. SAMUEl HENDEL, THE SOVIET CRUCIBLE 210-11 (5th ed. 1980).

132. For example, Article 62 of the 1977 Soviet Constitution obligates Soviet citizens to "safeguard the interest of the Soviet state" and "to enhance its power and prestige." Id. at 210; see also Sadurski, supra note 130 , at 52 .

133. Inga Markovits has noted that Stalin's Constitution of 1936 contained 16 articles on fundamental rights and the Soviet Constitution of 1977 contained 31 such articles, but "under neither constitution could or can a citizen sue the state to enforce his constitutional rights." Inga Markovits, Law or Order-Constitutionalism and Legality in Eastern Europe, 34 STAN. L. REV. 513, 603-04 (1982).

134. See Inga B. Mikhailovskaya, Constitutional Rights in Russian Public Opinion, 4:1 E. EuR. Con. REV., Winter 1995, at 70.

135. Id. at 71 .

136. Id.

137. Id. at 72 .

138. Id.
} 
demning an innocent [person] wrongly accused" or by "letting a genuine criminal go unpunished." 139 Most people (49\%) were more concerned with letting a criminal go unpunished, while only a minority (37\%) were concerned about wrongly condemning an innocent. ${ }^{140}$ This result is contrary to the view expressed by a sample of Russian jurists, although eighteen percent of them also thought that acquittal of the guilty is a worse defect than condemnation of the innocent. ${ }^{141}$ This paternalistic model of justice and protection of individual rights was also evident on other points as, for instance, where forty-one percent of the respondents favored preserving the old system of requiring administrative permits to reside in cities, forty-two percent thought that some categories of workers should not have the right to strike, and nineteen percent thought that anti-government organizations should be outlawed. ${ }^{142}$

When asked whether their rights had been violated in the last three years, thirty percent answered that they had been, twenty-seven percent answered in the negative, and a surprisingly high percentage-forty-three percent-were unable to answer. ${ }^{143}$ Of those who felt wronged, more than half $(53 \%)$ did not appeal to any authority, although only twelve percent wished to behave in this manner. ${ }^{144}$ Only twenty-four percent of those who claimed that their rights had been violated in the past three years could specify the right that had been violated, and, of those, seventy-eight percent identified socioeconomic rights, while six percent indicated rights violations that lay within the jurisdiction of the police. ${ }^{145}$

Preoccupation with socioeconomic rights is not surprising when a country undergoes a drastic economic decline and its citizens are struggling to emerge from the crisis. Moreover, as Professor Mikhailovskaia concluded from her study, "the Russian public generally interprets the personal rights and freedoms inscribed in the constitution through the prism of paternalistic habits and expectations." ${ }^{146}$ Thus,

[t]he social significance of personal rights and freedoms has not yet been understood by broad segments of the population. At the same time, variation in the distribution of responses among age and social groups suggest that young people, as well as individuals participating in the private sector of the economy, are more devoted to democratic principles than are average citizens. ${ }^{147}$

On the whole, this study of Russian attitudes about rights at the advent of democracy leaves us with the image of the average Russian citizen as one over-

139. Id.

140. Id.

141. Id.

142. Id. at 73 .

143. Id. at 74 .

144. Id. Professor Mikhailovskaya notes that "[t]his gap suggests that the individual's perception of his own helplessness in the face of the state machine is widespread in public consciousness, and that the rights inscribed in the Constitution are considered purely declarative." Id.

145. Id.

146. Id. at 76 .

147. Id. 
whelmed by unspecified abuses of subjectively felt socioeconomic "rights." Neither the self-organization of civil society nor democratic representation is thought capable of remedying these perceived abuses; the average Russian assumes that they can be remedied, if at all, only by the administration and the courts.

This expectation that welfare will be guaranteed by the state is widespread among the inhabitants of the post-communist world, and Russians are not exceptional in this respect. A series of surveys which the principal author conducted in Poland during the years 1988 to 1996, using a representative national sample, produced the following results, among others, concerning the scope of the state's duties towards the citizen:

TABLE 1

DO YOU CONSIDER IT A DUTY OF THE STATE TO PROVIDE FOR EVERYBODY? (ANSWERS “YES” IN \%)

\begin{tabular}{|l|c|c|c|c|c|}
\hline State has a duty to provide everybody with: & $\underline{1988}$ & $\underline{1990}$ & $\underline{1992}$ & $\underline{1994}$ & $\underline{1996}$ \\
\hline Well-being & 56 & 33 & 34 & 42 & 42 \\
\hline Permanent job matching citizens' skills & 91 & 79 & 80 & 75 & 76 \\
\hline $\begin{array}{l}\text { Permanent job, even if not matching any } \\
\text { skills }\end{array}$ & 71 & 69 & 76 & 76 & 71 \\
\hline Minimum social income & 93 & 94 & 96 & 95 & 95 \\
\hline $\begin{array}{l}\text { Opportunity to present one's own political } \\
\text { views in public }\end{array}$ & 70 & 68 & 67 & 75 & 76 \\
\hline Right to emigrate & 72 & 72 & 74 & 73 & 74 \\
\hline Religion taught in schools & 81 & 79 & 77 & 79 & 85 \\
\hline $100 \%=$ N = & 926 & 898 & 1,319 & 983 & 1,116 \\
\hline
\end{tabular}

Survey made by OBOP [Center for Public Opinion Research].

Although the transformation of the regime in 1989 seems to have produced a marked decrease in the socioeconomic expectations of citizens (except with respect to the provision of a minimum income), it is obvious that high expectations with respect to socioeconomic entitlements remain part of the bundle of rights to which the average Pole feels entitled. It is also noteworthy that, as the course of democratization progressed, the level of expectations concerning political and civil liberties and freedoms did not decline. Over time, the frequency of answers supporting the transformation steadily increased, as did the frequency of answers indicating respect for law. A majority (84\% in 1988, and $70 \%$ in 1996) thought that a citizen should fulfill her duties toward the state only if the state cares for the citizen's rights and interests. ${ }^{148}$ It also appears that

148. Jacek Kurczewski, Demokracja pod rzadami prawa. Przeglad doswiadczen [Democracy Under the Rule of Law. Review of Experience], RocZNIKI NAUK SPOLECZNYCH KUL, XXII-XXIII, 1994/95, at 317-19. The findings for 1996 are contained in the principal author's unpublished research files. 
the law-abiding and tax-paying citizen demands more than the minimum of basic civil and political rights.

In the general area of legal culture, the most important comparative research undertaken in the post-communist region after 1989 was the Project on Orientations Toward Law and Normative Ordering. ${ }^{149}$ The nations compared in 1996 and 1997 included post-Communist Russia, Poland, Hungary and Bulgaria, the "old democracies" of the United States and France, and the "young democracy" of post-authoritarian Spain. ${ }^{150}$ The research, which was coordinated by Felice Levine and Chantal Kourilsky-Augeven within the framework of the Law and Society Association, included some of the leading sociologists of law from the subject countries. Although conflicts occurred (which is not uncommon in collective enterprises involving participants with unequal bargaining power), several Polish and Hungarian scholars produced work that shed new light on the transformation to democracy and its obstacles. Grazyna Skapska compared Spain and Poland; ${ }^{151}$ Maria Borucka-Arctowa studied attitudes towards rights and freedoms; ${ }^{152}$ and Iwona Jakubowska-Branicka interpreted the overall findings in terms of authoritarianism, dogmatism, and legalism. ${ }^{153}$

According to Professor Skapska, the most striking result is that, several years after the formal restoration of the Rule of Law, Poles still are ambivalent about law. ${ }^{154}$ On the one hand, they believe that the law should be obeyed and respected. ${ }^{155}$ On the other hand, the same respondents justify ignoring and disobeying the law in specific circumstances, sometimes on moral grounds, but also based on self-interest. ${ }^{156}$ It appears that laws are accepted, but in principle only, with room left for idiosyncratic judgment that places the will and interests of the individual above those of all others, including the constitutional democratic state. In Spain, according to Professor Skapska, the concept of a legal state is closely linked with the performance of state officials and their respect for the law, while in Poland the concept of the legal state consists of the protection of civil and human rights and therefore has a much more substantial, but also anti-statist, meaning. ${ }^{157}$ If one considers that about sixty-five percent of the

149. J.L. Gibson and G.A. Caldera, The Legal Cultures of Europe, LAW \& SoC'Y REV. 30(1), 1996, at $55-58$.

150. $I d$.

151. Grazyna Skapska, Civic and Legal Cultures in Spain and Poland, 2(126) POLISH SoC. REV. 122, 223-37 (1999).

152. Maria Borucka-Arctowa, Postawy wobec praw I wolnosci obywatelskich oraz praw socjalnych w starych I nowych demokracjach [Attitudes Toward Civic Rights and Freedoms and Social Rights in Old and New Democracies] in PRAWO I LAD SPOLECZNY [LAW AND SOCIAL ORDER], Festschrift for Professor Anna Turska, 222-24 (Grazyna Polkowska, ed., 2000).

153. See generally IWONA JAKUBOWSKA-BRANICKA, CZY JESTESMY INNI? CZYLI W Poszukiwaniu Absolutnego Autorytetu [ARE We DifFerent? OR, In SeArch of ABSOLUTE AUTHORITY] (Institute for Applied Social Sciences, Warsaw University 2000).

154. Skapska, supra note 151, at 123-37.

155. Id. at 234 .

156. Id. at 235 .

157. Id. at 236. Here, Professor Skapska refers to the emphasis which the principal author has previously placed on the long-standing Polish tradition of rights as a basis for all efforts to establish a civil 
Spanish sample-compared to eleven percent of the Polish sample-would condone breaking the law when it is in one's own interest to do so, it would seem that Spaniards treat law much more as a technicality than do Poles. Professor Skapska also observes that civility plays a crucial role in attitudes towards the legal state in Spain, while in Poland an egalitarian expectation plays this role. Professor Skapska interprets the attitudes reflected in the general samples by reference to the institutional history of both countries, seeing the legitimacy of the constitutionally guaranteed legal state as a decisive factor in the process of democratic transformation and the development of civil society. ${ }^{158}$ The same set of data also has been subject to another type of interpretation, which emphasizes the social psychology of totalitarianism and takes the public attitude of legalism, rather than the legal state, as the point of reference. ${ }^{159}$

Iwona Jakubowska-Branicka discusses the social psychology of totalitarianism and then states her hypothesis that "[i]n the post-totalitarian societies respondents more often than in countries of old democracy will be dogmatic, and thus anti-democratic in their attitudes." ${ }^{160}$ According to Professor Jakubowska-Branicka, this hypothesis was corroborated "in principle" by the survey findings: The liberal world view is found most frequently in the older democracies, while the dogmatic world view is more frequent in the former communist countries. $^{161}$ In a review of Professor Jakubowska-Branicka's book, the principal author of this essay pointed out that one might refine the analysis by attempting to distinguish between "Totalitarian effect" and "Communist effect," a distinction which is lost if the post-Communist societies are contrasted en bloc with the others, without regard to whether each passed through any sort of totalitarian-authoritarian experience. ${ }^{162}$ "Exceptions" are both symptomatic and problematic: Post-Communist Hungarians are less often dogmatic than French "ancient democrats," while "young" Spanish democrats are closer to the Americans than to French democrats. ${ }^{163}$ In light of the initial hypothesis, it is Spain, rather than France, that presents the anomalous case. In post-Franco Spain one would expect, following this line of thinking, a medium level of liberalism and dogmatism.

There are two possible explanations for why the predicted correlation does not occur. The first is that the specific "Communist effect," and not the more general "Totalitarian effect," explains why Russians, with a much lengthier experience of communism, do not differ from their Western neighbors in Poland or Bulgaria. The second explanation is that democracy in Spain, although

and democratic society throughout the decades of communist rule, such as the riots of 1956, 1957, 1970, and 1976, and the emergence of Solidarnosc after the summer strikes of 1980. See JACEK KURCZEWSKI, THE RESURRECTION OF RIGHTS IN POLAND (1993).

158. Skapaska, supra note 151, at 237.

159. JAKUBOWSKA-BRANICKA, supra note 153, at 198-242.

160. Id. at 122 .

161. Id. at 277.

162. Jacek Kurczewski, Opinia o dorobku naukowym dr I, Jaubowskiej-Branickiek [Academic Review of Dr. I. Jakubowska-Branicka], Institute of Applied Sciences, Warsaw University (Jan. 31, 2001).

163. Jakubowska-Branicka, supra note 154, at 277. 
"new," is about fifteen years older than democracy in the former communist countries, and that even that relatively short time has sufficed to erase the "totalitarian experience." Yet another interesting fact is that Spain and Hungary, two countries with recent experience of civil war (in both cases with foreign intervention), are comparable in their rejection of both fascism and communism, while in some other post-communist countries, as well as in France, the strength of dogmatism, together with tolerance (if not sympathy for) communism, is much greater. In general, the investigation of the post-communist legacy is rightly perceived to have great significance by Polish scholars, but Communism neither fell from the sky onto Europe nor was blown in with the winds from the East. Like Fascism and National Socialism, Communism remains a distinctively indigenous European intellectual product.

The problem of the political meaning of legalism reemerges in the part of Professor Jakubowska-Branicka's study dealing with questions about the authority of law. We learn, first, about a major difference between American and European attitudes. On the one hand, we learn that ninety percent of Americans support the absolute authority of law, while Eastern European support equals only fifty-nine percent, and Western European support is lower still-at fifty-one percent. ${ }^{164}$ More surprising is the second finding reported in the book, that is, that there are two drastically opposing attitudes in relation to breaking the law. ${ }^{165}$ In Poland, Bulgaria, and France, an average of ninety percent of respondents justify bribery, theft of company property, and tax evasion, while in the United States, Spain, and Hungary only three percent of the representative national samples declare such tolerance. ${ }^{166}$ Whether it is an artifact (contrary results were reported by Professor Skapska in her Polish-Spanish comparison $^{167}$ ), or an expression of a totally distinctive civic culture, remains open for further inquiry, but certainly the "Communism effect" has to be excluded here, and other cultural forces should be invoked in order to explain these patterns.

What was observed by Professor Borucka-Arctowa in her findings created more discomfort for Polish sociologists of law. ${ }^{168}$ According to her findings, the importance attached to freedom of expression and association was relatively low in those countries that began the whole process of democratization by emphasizing the importance of those freedoms, especially in the trade union movement, and that the lowest degree of importance attached to these rights

164. Id. at 239 .

165. Id. at 212 .

166. Recent survey research in the United States suggests a possible correlation between acceptance of cheating and law enforcement policies. As the Internal Revenue Service has devoted fewer resources to audits in the past several years, polls have suggested a higher volume for some cheating. In $1999,87 \%$ of respondents thought that "any cheating" was unacceptable; that number fell to $76 \%$ in 2001. As Audits Declines, Fewer Taxpayers Balk at a Bit of Cheating, New York Times, January 19, 2002, at A9 (national edition).

167. Borucka-Arctowa, supra note 152, at 234-35.

168. Id. at 222-44. 
and freedoms was in Hungary. ${ }^{169}$ Professor Borucka-Arctowa suggests that this paradoxical result can be explained in two ways. ${ }^{170}$ First, she points out that political accomplishments were overshadowed in most cases by the burden of economic transformation shock and rising unemployment; second, she develops the argument that once freedom of association was established, the proliferation of political parties, associations and trade unions led to another shock and disenchantment with pluralism, perceived now as chaos and disorder. ${ }^{171}$ Contrary, however, to another stereotype that attributes the post-communist mentality with a "homo sovieticus" dependence on the benevolent state, Professor Borucka-Arctowa observes a general expectation of assistance and active social policy from the state, in both the "old" and the "new" democracies of Europe. $^{172}$

IV

\section{SOCIAL THEORY OF RIGHTS REVISITED}

This brings us to the question: What rights? Recently, Thomas Janoski further developed the conceptualization of rights, which was begun by T.M. Marshall and has been elaborated by Rheinhard Bendix. ${ }^{173}$ In Professor Janoski's new reading, citizenship rights include participation rights: workers' rights to democratic participation in firms, labor markets, and capital markets. ${ }^{174}$ Following the legal distinction between "status" and "capacity," Bendix contrasts "being," meaning that one has rights, with "doing," which means that one has the meta-right to create rights. Bendix's model implies a cross-classification of social institutions (public and private) and social action (being and doing), with three types of rights (Marshall's legal, political, and social rights) ${ }^{175}$ to which Janoski adds the fourth category of active rights in the private arena (participation rights). ${ }^{176}$ Participation rights logically supplement legal or civil rights like freedoms of speech, property, religion, and association, which are passive in the public arena; political rights (procedures for creating new laws, including electoral law and powers of political action for private organizations), which are active in the public arena; and social rights, which are public interventions into the private sphere in aid of the claims of citizens claims to economic existence. ${ }^{177}$

This typology is intriguing from the perspective of the Petrazycki-Lande theory of juridical nexus, which posits three basic types of jural relationships between the individual and the collective actor:

169. Id. at 231 .

170. Id. at 230 .

171. Id. at 230-32.

172. Id. at 242 .

173. THOMAS JANOSKI, THE POLITICAL ECONOMY OF UNEMPLOYMENT 16 (1990).

174. Id.

175. Id.

176. Id. at $16-19$.

177. Id. 
(1)one's right to accipere, to which the Alter duty to dare corresponds, as when the debtor has a duty to repay the debt which is subject to the positive claim;

(2)one's right to non pati with corresponding Alter's duty of non facere, as when one enjoys the right to privacy which has to be respected by forbearance or non-actions of the others, the protective rights;

(3)one's right to facere correlated with duty to pati, to suffer the actions, for example, of the state against the criminal. ${ }^{178}$

The complexity of this process is perhaps best understood if one points to one important aspect of emancipation. As the principal author has stated,

emancipation is self-reflexive in that sense, that in liberating the space of human activity it allows the kinds of activity that had not been possible before or possible in a suppressed and hitherto immature way, like commerce which was practice[d] privately on the mass scale under ... socialism but without the proper banking system, or widespread private sexual license without a public sex market. The more freedom, the more also of the variety [of] . . . manifestations of it that add together to the sensation of disorder and anomie. Proliferation of industries accompanies proliferation of political parties; plurality of TV channels rivals ... plurality of life styles. This is characteristic of the emancipation as ... revolution, with passage of time... heterogeneity ... becomes more limited due either to the concentration processes on the market or to the selective attention of consumers. More likely, however, the plurality continues, but as it might be observed in Polish politics, there is a growing gap between "serious" politics and the political niche politics of the radical left, right, feminism, ecologism, pacifism, and monarchism that in contemporary societies allow individual [sic] to identify themselves aside from the main bulk of public politics. ${ }^{179}$

The self-reflexive character of emancipation leads to tensions and conflicts. The best example to date of the basic structure of these conflicts in Poland was provided in 1992, when, during the course of preparing the new constitution, then-President Walesa introduced his draft of the Charter of Human and Civic Rights to be accepted by the Sejm. ${ }^{180}$ Both liberal parties supported the draft unconditionally. ${ }^{181}$ The post-communist Left supported the draft, but also added its own draft of the Social Charter. ${ }^{182}$ The Catholic Right answered by criticizing both drafts and promising its own draft of the Charter of Family Rights. ${ }^{183}$ This triangular confrontation epitomizes the structure of the contradictions within the Polish process of emancipation. As time goes by, and emancipation becomes more extensive, rights expand and come into conflict. Individual civil and political rights may include both the right to expect social benefits and the right not to be bothered by concern for those who have failed in the new economic competition; the right to divorce contradicts the right of a child to have both parents at home; and the right to express one's views on abortion may in-

178. Petrazycki, supra note 128 , at 264-65.

179. Jacek Kurczewski, Transformation as Emancipation, 2(126) POLISH SoC. REV. 197, 205-6 (1999).

180. Jacek Kurczewski, The Politics of Human Rights in Post-Communist Poland, in HumAN RIGHTS IN EASTERN EUROPE 111, 113 (Istvan Pogany ed., 1995).

181. Id. at 114-15.

182. Id.

183. Id. 
terfere with the peace of others. It is nonetheless tempting to check the usefulness of the basic conceptualization of rights. Social rights obviously represent an entitlement to accipere social benefits that are imposed as active duties on the state. These rights are positive claims by an individual against the state, even if the state's corresponding obligation to be fulfilled through the imposition of taxes upon individuals and a consequent redistribution of income. On the other hand, civil or legal rights fall under the protective rights category in Petrazycki-Lande's scheme: One's freedoms of association, speech, and property, as well as similar rights, must be respected by others, including the state, and, with this duty comes a corollary, that is, that the state has a right to punish others for trespass of such individual rights. ${ }^{184}$

In light of the Polish experience, it might also be added that citizenship need not be conceptualized entirely as individual rights, or, at least, that full citizenship is sometimes enjoyed by the individual through participation in a community. The controversy between individualistic and collective concepts of rights cannot be excluded at the highest level of interpretation. Solidarnosc's struggle for recognition by the communist authorities from 1980 to 1989 does indeed reflect both the process of implementation from the bottom up of the individual's freedom of association and the process of granting to a collective entity the right to participate in public life at both a national and a company level. After 1981, authorities acknowledged the freedom of individual employees to associate within any trade union other than Solidarnosc; the issue was how to force the communist authorities to acknowledge the corporate existence or "being" of Solidarnosc. ${ }^{185}$ In abstract terms, this question might be defined as whether associations themselves may have the right to associate with each other. While changing the Polish law of associations in 1989, the Solidarnosc side chose to abolish such right of associations, as a necessary step to dissolving the totally uncontrollable structures that were sedimented through decades of bureaucratization of voluntary activities in society. ${ }^{186}$ In retrospect, it now seems that the anti-communists unconsciously applied the individualistic philosophy of rights to the same purpose as the communists, who, after the introduction of martial law, allowed individual independent trade unions to represent workers in the enterprises, but prevented them from associating with each other at the national level, so as to preclude any re-emergence of Solidarnosc. Communities have a life of their own even if it is possible to reduce it to the lives of their members. This fact is well known in the area of ethnic minority rights: To grant each individual the right to practice and protect national identity means something different than to grant the legal right to the minority as an entity. The contradiction between subjective definitions of nation and the social reality of how nations function is another relevant fact.

184. Petrazycki, supra note 128 , at 264-65.

185. See JACEK KURCZEWSKI, RESURRECTION OF RightS IN POLAND, supra note 12, at 432.

186. The principal author was a member of the Solidarnosc negotiating team on the law of associations. 
Freedom of association thus entails the right to create with others a new social body that may be granted full corporate rights, much like the right to national self-determination entails the right to form a nation state with prerequisites (however obsolete) of sovereignty. This type of collective rights does not seem well-developed in the classical social theory of rights. The Polish (in this case) Catholic plea for recognition of rights of family meant, among other things, the rights of families to associate with each other as the distinguishing mark of the family as an emergent community-qua-corporation. The controversy between liberals and Catholics was not about the dignity of the human being, which both acknowledged, but about the claim of exclusivity (or priority) of the individual as the subject of rights. At a higher level of abstraction, the political conflict in parliament appears to have been focused on two sets of oppositions: (1) positive claims or social rights of the individual (Left) versus positive claims or social rights of family (Right); and (2) protective or civic and legal rights of the individual (Liberals) versus positive claims or social rights against the individual through the state (Left and Right). In the post-communist context, it therefore emerges that the so-called collectivism of the Left amounted to the totalitarian predominance of the polity over the individual elements of atomized society. The Liberal response would be to make the individual as strong as possible by making both polity and other collectivities dependent on the individual, while the Right stresses the role of collectivities (family, nation, church) against both the state and the individual.

A proper reformulation would take into account the distinction which Janoski made in a practical way when he emphasized the complex character of citizenship rights, and, hence, the need to recognize the existence of individual rights against private organizations. ${ }^{187}$ Not surprisingly for an American scholar, the private arena for Janoski is predominantly that of the economy. ${ }^{188}$ From a Polish perspective, the economy-like any other area-may be public or private. If by "private" we mean the area that is not individual, but is left for the emerging private collectivities such as the family and the business corporation, that is, civil society in some sense, then the meaning of the scheme changes. The right to participate does not disappear, but it becomes the right to participate as an individual in conducting the affairs of the public (state) or private enterprise, political or economic. Political participation and economic participation are analytically parallel to each other. Civil rights include the right to participate in joint economic activity with others.

Theoretically, the emancipation debate might be summarized by the following table:

187. THOMAS JANOSKI, CITIZENSHIP AND SOCIETY 29-33 (1998).

188. Id. at $12-17$. 
TABLE 2

INDIVIDUAL VERSUS SOCIAL WORLD-FOUR DIRECTIONS OF RIGHTS

\begin{tabular}{|l|l|l|}
\hline & \multicolumn{1}{|c|}{ Public Arena } & \multicolumn{1}{c|}{ Private Arena } \\
\hline & Rights Against the Polity & $\begin{array}{l}\text { Rights Against the } \\
\text { Collectives }\end{array}$ \\
\hline Positive rights to receive & IV. Social Rights & I. Participation Rights \\
\hline $\begin{array}{l}\text { Protective rights to be } \\
\text { tolerated }\end{array}$ & III. Political Rights & II. Civil Rights \\
\hline
\end{tabular}

Although fitting the historically developing categories into a four-fold table may seem to stretch them too far, this exercise provides some insight into the logic of the historical and social process. Privatization as emancipation covers liberation both from state control and from control by other collectivities. The contradiction of the emancipation process is that it also allows other (private) collectivities to try to assert themselves at the expense of individual freedom. The privatization of the body is the assertion of the individual right over family and other obligations, while the privatization of property is the assertion of individual independence from the claims of others, whether as a polity or as individuals, and the privatization of anima reasserts the political freedoms (freedom of expression) of the individual. The civil rights of the individual include both the freedom to establish or join collectivities such as families, associations, political parties, and other corporate entities at the will of the contracting partners, and also the freedom to withdraw from those collectivities according to one's own choice.

Positive claims against private collectivities constitute another set of "social rights." Although these claims are most often linked to voluntary participation in the economic enterprise, they also include such things as the right to be nurtured and cared for by parents. Social rights make sense when they are understood as the right to benefit from the community in which one belongs and in which one participates. In addition to social rights against the private enterprise, one may posit participation rights against the polity. In a democracy, this nexus between the citizen and the polity is fundamental. The central problem rests in the fact that one cannot discuss the scheme without assuming some basic right that constitutes the scheme. These rights in fact should be called civic rights: the right to constitute the civil, private sphere, and the right to participate in the polity, at least in the sense of having certain rights against it. On the other hand, individual freedom consists of freedom both from the communities and from the polity. Thus, a more inclusive scheme should take into account all three of these perspectives at one time. This formulation does not exclude conflict. On the contrary, it points to the possible major areas of conflict among 
rights within society. Janoski has moved to greater elaboration of his theory of rights since the position he articulated in $1990,{ }^{189}$ but his later work has continued to use the basic fourfold scheme he introduced then, and, as modified, it remains a useful mechanism for investigating these issues. ${ }^{190}$

Social citizenship is a broad category - a bundle of rights that belong to the citizen in a particular society and accord to each citizen a status of equality with others in the society. It is usually linked with state citizenship, but that is not necessarily the case. Civil society is composed of the citizens who enjoy the full rights of social citizenship, although a more limited definition is also possible. While the contents of citizenship are changing, the core remains stable. On the other hand, the social rights that are enshrined in abundance in Marxist constitutions have not provided those societies with an adequate basis for the development of civil society as such. The security of life and property, privacy, freedom of expression and association seem basic, even if they may sometimes be traded for the security of dependence. If the key element of citizenship is independence (similar to the sovereignty of the community at the collective level), civil or legal rights necessarily are fundamental to such citizenship. But with its development, other rights-political, social, and participatory-are an important, though not a necessary, element. The political process in civil society involves debate on the scope of social citizenship and the rights to be included in it. The debate on the Social Charter within the European Union and the debate on the subject of the social rights in the new Polish Constitution of 1997 are good examples of that process.

\section{$\mathrm{V}$ \\ SUMMARY}

It is obvious now how great the differences were, and remain, among the countries that formerly had been put under the Moscow-centered political and military control of the Communist bloc. In the past, shades of the same red color made for important differences among the countries of the communist bloc: the more liberal countries like the Polish People's Republic and the Hungarian Socialist Republic; the politically repressive but economically prosperous countries such as the German Democratic Republic, the Czechoslovak Socialist Republic and the People's Republic of Bulgaria; and, finally, the politically repressive but strongly nationalistic and more independent Romanian Socialist Republic. Today, the differences are even more pronounced. In the former Soviet Union and in the former Yugoslavia-now two multinational, federal states-much more heterogeneity is apparent than was visible under the dictatorial Communist Party regimes. These differences are evident not only in the economic sphere, but in the political systems that have emerged within the last twelve years as well.

189. Janoski, supra note 187.

190. Id. at 30-33. 
On the one hand, one sees a grouping of authoritarian regimes in the former Soviet Central Asia. Kazakhstan, Tajikistan, Kyrghizstan, Uzbekistan, Turkmenistan, and (for cultural reasons belonging to the same area) Azerbaijan present similar traits even if local practices differ. The strongman is in charge of the state, and presidential administration transcends civil government and civil society, filling the void that was left by the disappearance of the Communist Party administration. Each of these countries has all the adornments of a constitutional parliamentary democracy-its own parliament (usually with more than one party), a president, a constitution, and a constitutional tribunal-yet the aggrieved citizen finds no way to pursue his or her complaint against the abuse of constitutional freedoms and rights. Marxism-Leninism gave way to a nation-building ideology that minimalizes the autonomy of citizens and maximizes the role of the central state power in economic development. The social foundations that are essential to democracy and civil society do not exist: Islamic forces are either actively persecuted or kept under state control; civil society is limited to a number of small non-governmental organizations living on permanent subsidies from the West and kept from having any real influence in the society; business is based upon a corrupting link between Western investment and state-controlled large enterprises and companies; and every appointment in the justice system and election in the self-government is subject to the approval of the authoritarian administration.

The situation in Central Asia sharply contrasts with that of Central Eastern Europe, including the three former Soviet Baltic states of Lithuania, Latvia, and Estonia. Although the local differences within this region are significant, the countries that were independent between World War I and World War II generally demonstrate significant similarities in their aspirations to democracy and the rule of law. In almost all of these countries, the inter-war period was full of adventures with various forms of authoritarian rule, but there was also an indigenous democratic tradition that remained a significant element of local culture, even as it was suppressed. The "resurrection of rights" and the embracing of democratic institutions after 1989 illustrate that sometimes it is not only the dominant political system that defines the local political culture, but also the opposing trends and forces. The cogency of that theory was also demonstrated in Germany following World War II. Despite the long period (1933-1945) of the totalitarian National Socialist dictatorship that was introduced in democratic elections and supported by a majority, the German democratic tradition was strong enough to overcome totalitarian proclivities once its military power had been crushed and compromised in the eyes of the people. Similarly, one might have expected that the former Czechoslovakia, the only country with an unbroken record of democratic governments during in the years 1918-1938, would have been better prepared for democratization. That has not been the case, however; its re-engagement with the rule of law in the post-communist period does not seem to have differed significantly, either positively or negatively, from the experience of other societies of the area. 
Another lesson that might be drawn from the history of de-communization is that democratization has its own institutional logic. Thus, Hungary and Poland are two countries that have an undoubtedly good recent record on the protection of human rights and the rule of law. In both cases, the institutions of the Constitutional Court and the office of the Ombudsman have become part of the constitutional structure of the country, but the actual system of institutional protection of human rights has developed quite differently in the two countries. In Poland, the Constitutional Court was created in 1985, as part of an attempt to reform communism from within, and was thus made weak from its creation. The Polish Constitutional Court continued to function as a weak institution even as late as 1998, for the simple reason that it was in the clear interest of political actors of the new democracy to keep it weak. In that way, it was unable, in important circumstances, to overrule decisions of the legislature and the government. Thus, Polish expectations with respect to the protection of human rights became concentrated in another institution, that of the Ombudsman, who, in the first years of transformation, became the second most visible public figure, after the president, and the single most popular individual actor on the public scene. In Hungary, by contrast, the anti-communist opposition wished in 1989 to reinforce the newly-created Constitutional Court as much as possible, even investing it with power to invalidate legislation before it becomes effective. Created in this way, the Hungarian Constitutional Court worked to acquire even greater authority by becoming active in the field of basic rights and taking up the merits of individual cases, even when it was not authorized by law to do so. Not surprisingly, the institution of ombudsman remained a parchment protection in Hungary; there was little need for its development or activity.

Finally, let us observe that the post-communist Bill of Rights is complex, usually extensive, and involves many generations of rights altogether. From Hungary, we hear a warning of danger with respect to such a mixture of civil, political, social and economic rights linked with the relatively efficient mechanism of legal protection:

[B]y constitutionalizing welfare rights and thus obliging the state to provide welfare services, the relatively poor countries of Eastern Europe are destined to wither to stagnation and eventual collapse, or to cavalier disregard of constitutional provisions. Such disregard will undermine the constitution's credibility. Actually, most Eastern European constitutions promise a fair number of social rights that are unenforceable in court, mandating that the government maintain welfare institutions, particularly a social insurance scheme....

Moreover, the language of the constitutions in Eastern Europe mandates (although not imperatively) the protection of social rights, while market development and deficit reduction are not constitutionalized aims. Creating market economies is an aspiration, while welfare is a requirement.

As a consequence, constitutional courts will assume the role of defending the poor, and even more, of the "respectable" impoverished classes, whatever the social 
costs. This attitude may result in a kind of judicial activism that destabilizes the constitutionally mandated, although imperfect, separation of powers. ${ }^{191}$

The senior author of this essay was himself frustrated in his attempts to limit the definition of constitutional rights in Poland, and to make them more ascetic. It is also the case, however, that socioeconomic reality is also composed of the people's expectations. Another result of his inquiries during the period 1988 to 1996 was that, while there was a sharp and quick increase in the sense of freedom after 1989, there also continued to be a sense of inequality. In 1989, people had not traded equality for freedom, since there was no equality could communism either, but they did expect a more equal social world, which can be accomplished either through direct redistribution or by an overall increase in well-being. Once the socioeconomic rights that abound in post-communist constitutions are traded for something else, the problem will disappear, but optimism is as bad a guide here as the attempt to undercut human hopes. If human rights brought us freedom, we must remember our debt. In the end, there is no way but to negotiate, and to give an accounting of all the costs and benefits (including those that are social) of introducing, implementing, and curtailing various rights, and to ensure the most participatory means for deciding basic priorities in the realm of rights, which themselves contain no limit to their own expansion.

191. Andras Sajo, supra note 107, at 32-33. 